\title{
The Peopled Scroll of the Great Palace Mosaic in Constantinople. New Perspectives
}

\section{İstanbul' daki Büyük Saray Mozaiğinin Akantus Dalları Motifi. Yeni Perspektifler}

\author{
Stéphanie DERWAEL*
}

(Received 15 February 2021, accepted after revision 10 September 2021)

\begin{abstract}
Many studies have been devoted to the mosaic of the Great Palace peristyle in Constantinople / Istanbul. To its style, influences and models, as well as to its dating or to the function of the room it decorated. But there is one element that has so far not aroused much interest: the peopled scroll that circumscribes the central panel. The iconographic, chromatic, and technical richness of this border make it much more than a simple ornamental frame. It is even a key element of the pavement. This type of border developed towards the end of the $2^{\text {nd }}$ century $A D$ in workshops on the Levantine coast on the basis of a Hellenistic pattern. The presence of foliate heads at regular intervals in the border contributed to the revival of this pattern inherited from the Greek world. Four heads of this type are partially preserved in the Great Palace Mosaic. But what is it really about? The analysis of the corpus of the Roman foliate heads and the contextualising of this pavement allow to specify the origin and meaning of these heads, but also to confirm the dating of the $6^{\text {th }}$ century $A D$, and to shed new light on the interpretation of the decorative program.
\end{abstract}

Keywords: Mosaic, Great Palace, peopled scroll, foliate head, Late Antique - Early Byzantine Art.

\begin{abstract}
Öz
Istanbul'daki Büyük Saray peristilinin mozaiği üzerine birçok çalışma yapılmıştır. Bu çalışmalar mozaiğin tarzına, etkilerine ve modellerine, tarihlendirmesine veya dekore ettiği odanın işlevine dairdir. Ancak şimdiye kadar pek ilgi uyandırmayan bir unsur bulunmaktadır: Orta paneli çevreleyen akantus dalları motifi. Bu bordürün ikonografik, kromatik ve teknik zenginliği, onu basit bir dekoratif çerçeveden çok daha fazlası haline getirmektedir. Hatta döşemenin önemli bir unsurudur. Bu tip bordür, IS 2. yy'ın sonlarına doğru Levanten sahilindeki atölyelerde Helenistik bir desen temelinde gelişmiştir. Çerçevede düzenli aralıklarla yapraksı başların bulunması, Yunan dünyasından miras kalan bu desenin yeniden canlanmasına katkıda bulunmuştur. Bu tipten dört baş, Büyük Saray Mozaiği'nde kısmen korunmuştur. Ama bunlar asıl ne hakkındadır? Roma yapraklı başlarının korpusunun analizi ve bu döşemenin bağlamsallaştırılması, bu başların kökenini ve anlamını belirlemeye, aynı zamanda IS 6. yüzyıla tarihlendirmeyi doğrulamaya ve dekoratif yapıların yorumlanmasına yeni bir ışı tutmaya izin vermektedir.
\end{abstract}

Anahtar Kelimeler: Mozaik, Büyük Saray, akantus dalları motifi, yaprak baş, Geç Antik - Erken Bizans Sanatı.

\footnotetext{
* Stéphanie Derwael (Chargée de recherches - F.R.S.-FNRS; Chercheuse associée de l'IFEA - Istanbul), Service d'Histoire de l'art et Archéologie de 1'Antiquité gréco-romaine, Université de Liège, Liège, Belgium. (D) https://orcid.org/0000-0003-4346-5134. E-mail: s.derwael@uliege.be
} 
The mosaic of the Great Palace peristyle in Constantinople (Figs. 1-2) is one of the most important artworks of Late Antique and Early Byzantine art, as well by the composition scale as by the variety of subjects or the technical mastery of the mosaicists. W. Jobst is familiar with this pavement, as director of the research and preservation project carried out jointly by the Turkish Ministry of Culture's General Directorate of Monuments and Museums, and the Austrian Academy of Sciences, between 1983 and 1997 (Jobst - Vetters 1992). He published several articles about the mosaic, providing a complete study in terms

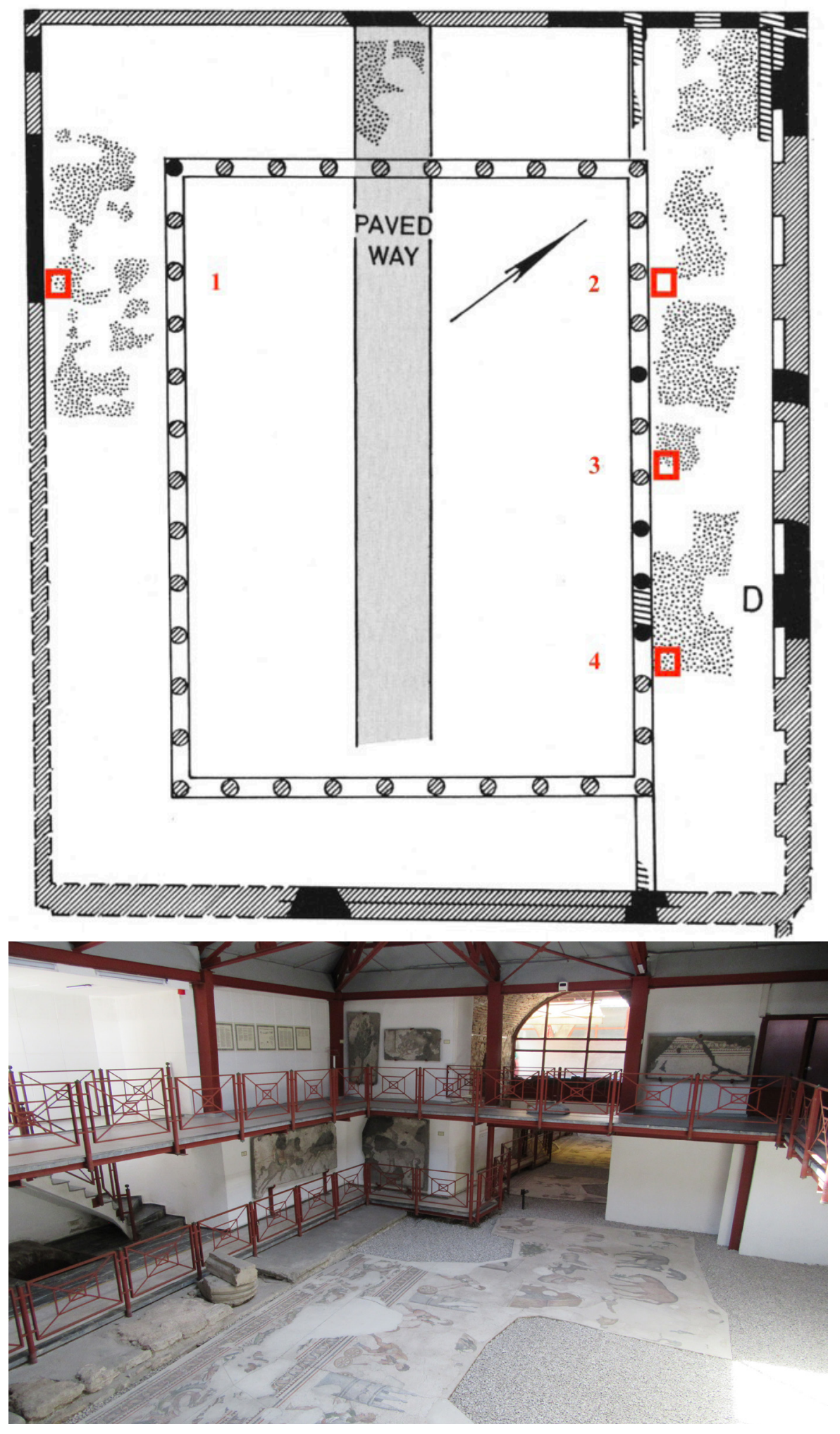

Figure 1

Map of the Great Palace peristyle with location of the four remaining foliate heads of the border, Constantinople (scale 1:500). 1) Fig. 3; 2) Fig. 4; 3) Fig. 5; 4) Fig. 6.

(Map from Hellenkemper-Salies 1987: fig. 2; annotations in red added by Stéphanie Derwael).
Figure 2

View of the Mosaic Museum, İstanbul. Photo: Stéphanie Derwael. 
Figure 3

Foliate head of the Great Palace mosaic,

Constantinople.

Photo: Stéphanie Derwael.

Figure 4

Foliate head of the Great Palace mosaic,

Constantinople.

Photo: Stéphanie Derwael.

of its implementation, iconography, and stratigraphic analysis of the area (Jobst 1987; 1995; 2005; 2006; Jobst et al. 1997). Many other researchers studied the subject (Brett 1942; Brett et al. 1947; Talbot Rice 1958; Trilling 1989; Cimok 2005; Parrish 2005; 2006; Bardill 2006; Westbrook 2019). However, two major issues still divide the scientific community: the dating of the mosaic and the meaning of its decoration. An element hitherto neglected by research has shed new light on these issues: the scroll border which circumscribes the central panel. Its iconographic, chromatic, and technical richness make it much more than a simple ornamental frame. Four of the foliate heads that mark its scrolls have survived (Figs. 3-6). Seemingly anecdotal in appearance, this motif is a key element of the rinceau. An element which helps to clarify the place of this pavement in the corpus of oriental and Late Antique mosaics, and which is part of the message conveyed by the decorative program (Derwael in print) ${ }^{1}$.
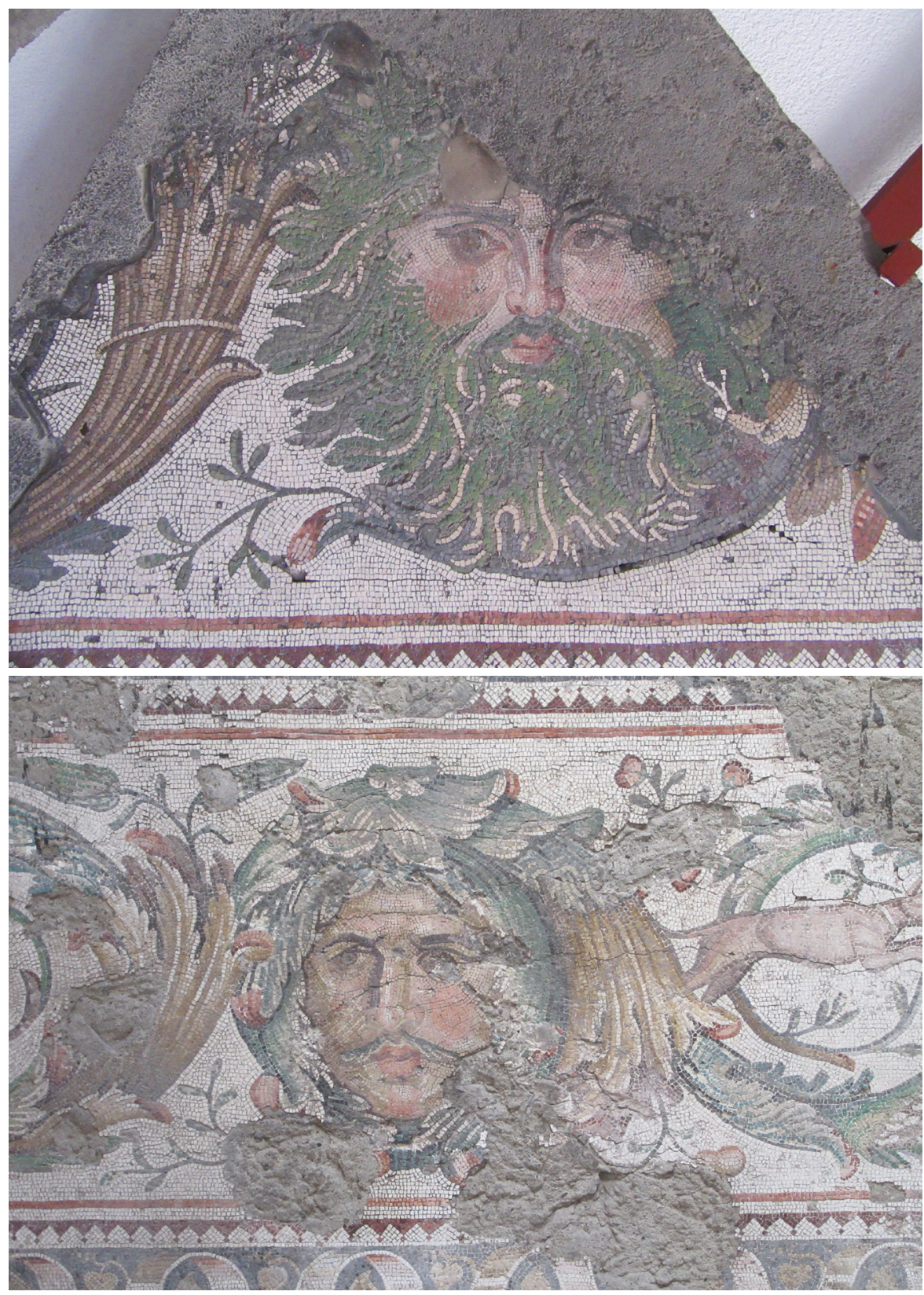

1 This research was the subject of a $\mathrm{PhD}$, now being published. I would like to thank those in charge for this issue of the JMR for giving me the opportunity to present some of the results of this survey here. For the illustrations and bibliography of the foliate heads cited in this article, and for the typology of the motif, please refer to this publication. The foliate heads inventoried in the Roman world can be found on the online database Diphuès, available on the website of the Université de Liège. 

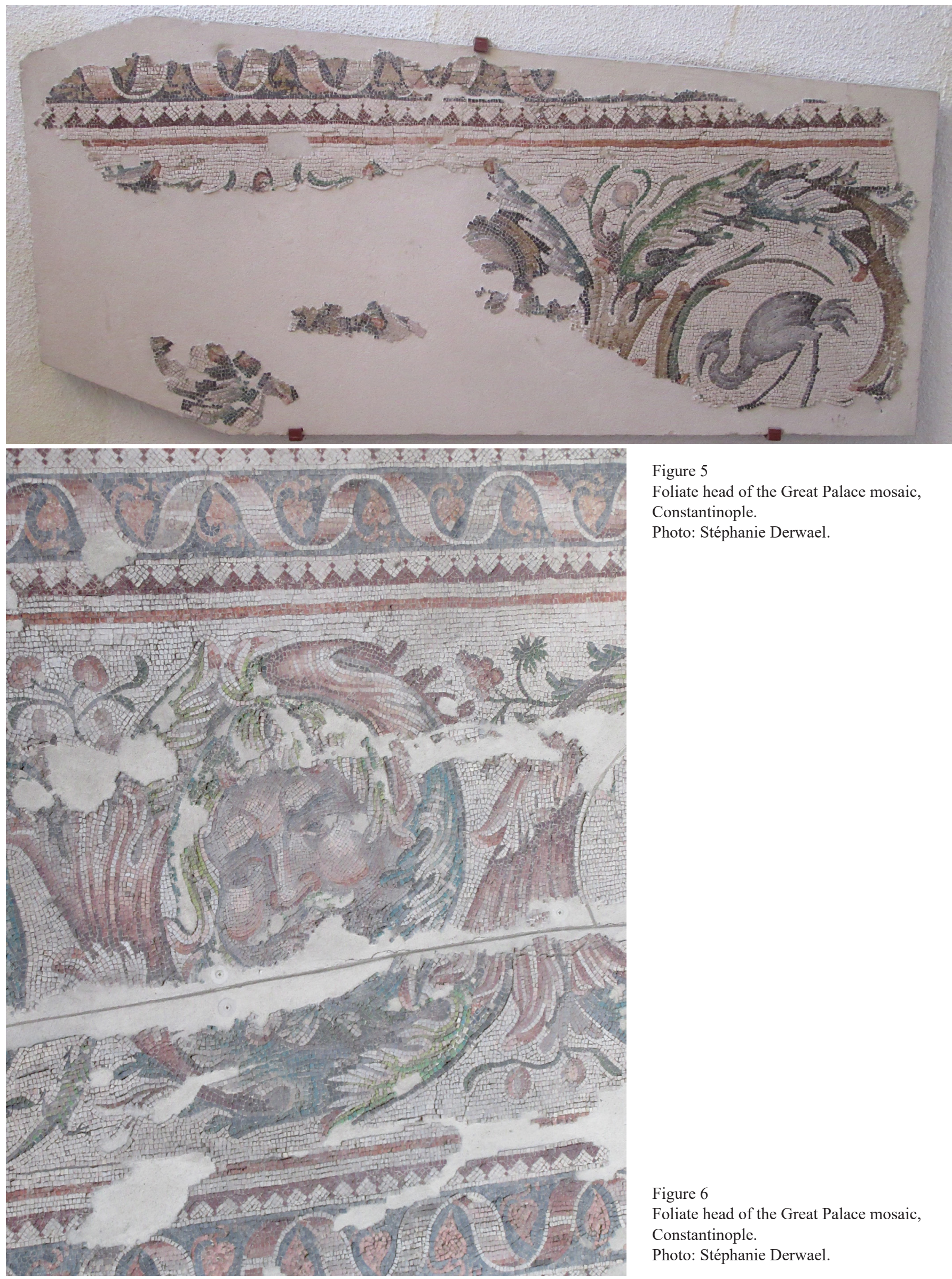

Figure 5

Foliate head of the Great Palace mosaic,

Constantinople.

Photo: Stéphanie Derwael.

Figure 6

Foliate head of the Great Palace mosaic,

Constantinople.

Photo: Stéphanie Derwael. 
The Great Palace mosaic is made up of a multitude of isolated scenes and figures organised in several registers on an even white background: hunting scenes, animal fights, children's games, bucolic, rural, or mythological scenes, or even fabulous creatures. This central panel is $6 \mathrm{~m}$ wide ( 20 Roman feet). It is placed between two borders of $1.50 \mathrm{~m}$ wide ( 5 Roman feet), each decorated with a wide rinceau, between two strips composed of simple blue, white and red filets, a saw tooth pattern with a poised tessera on the apex of the triangles, and a central three-dimensional polychrome undulating and twisted ribbon with a tendril terminating in an ivy leaf alternately inverted in each undulation.

The rinceau stands out against an even white background. It consists of long acanthus leaves in the codified colours of nature and seasons: green, blue, red, and golden ochre. The scrolls, alternately facing upwards and downwards, emerge from leafy windings resembling a cornucopia, sometimes adorned with thin golden rings. Young sprouts emerge here and there from the foliage, spawning into fine flowers or fruits, while all sorts of animals evolve in the foliage. In this rich and colourful vegetal environment, there is one more incongruous pattern: human heads with a vegetalised hair system (Figs. 3-6). The richness of the colours and the small size of the tesserae bear witness to the high quality of the work carried out: no less than 420-440 units per 10x10 cm make up the faces. In 1958, D. Talbot Rice had already noted the exceptional character of the motif (Talbot Rice 1958: 130):

The most important feature of the border, however, is the presence at intervals of great heads framed in the scrollwork; before the war two bearded heads representing Oceanus were unearthed; subsequently the great moustached head has been found. (...) the moustached head is virtually a portrait, one would almost think that of some barbarian chieftain, who had found his way to the Byzantine court either as an ambassador or as a prisoner. The physical appearance is that of a 'barbarian' rather than an inhabitant of the Roman world, and one would seek for parallels in Parthian or Sarmatian rather than in classical art.

The archaeologist's enthusiasm does not fail to arouse curiosity. However, the freedom of terminology he uses in this case, 'Oceanus', 'barbarian chieftain', reveals a poor understanding of the motif, which still leads to misinterpretation today. Although the face with the large moustache is no longer associated with the portrait of a so-called 'foreign' ruler, the identification with Oceanus has become firmly established in people's minds. But what is it about? How should we interpret this motif and what does it reveal about the Great Palace mosaic?

The foliate head appears in Rome in the second half of the $1^{\text {st }}$ century BC (Derwael in print: $\mathrm{n}^{\circ} \mathrm{P}-\mathrm{A}$.It-R.1). It is a combination of different iconic units inherited from Greek art, such as the foliage skirt of the Rankenfrau and Rankengott, applied here to the beard of a neckless head. This process is related to an inclination for mixing past forms, which is characteristic of Late Republican and Early Imperial eclecticism. It testifies to a valued reclaim of the Greek iconographic heritage. But the reworking of existing forms here results in an original creation, whose ornamental potential will then be fully exploited.

During the $1^{\text {st }}$ century AD, the foliate head benefits from the standardisation and diffusion of Italic wall decorations, to establish itself permanently in Roman visual culture. It then penetrates the various regions of the Empire as a result of their economic, socio-political, and urban development. Its transmission is part of the reclaim of a prestigious repertoire that functions as a marker of identity. In this respect, it is part of the Mediterranean cultural heritage common 
to the various provinces of the Empire and spread through Romanity. The 'Romanisation' of the living environment does not, however, imply the disavowal of local substrates. The assimilation of Italic decorative trends differs from one region to another, and local cultural specificities and iconographic traditions determine different levels of appropriation of the motif. Alongside the relatively homogenous trends common to the Empire, particular tendencies emerge. In North Africa, the mosaicists thus enrich the oceanic form of the foliate head, which celebrates the benefits of the sea and the cultivated land from which the region draws its economic wealth (Fig. 7).

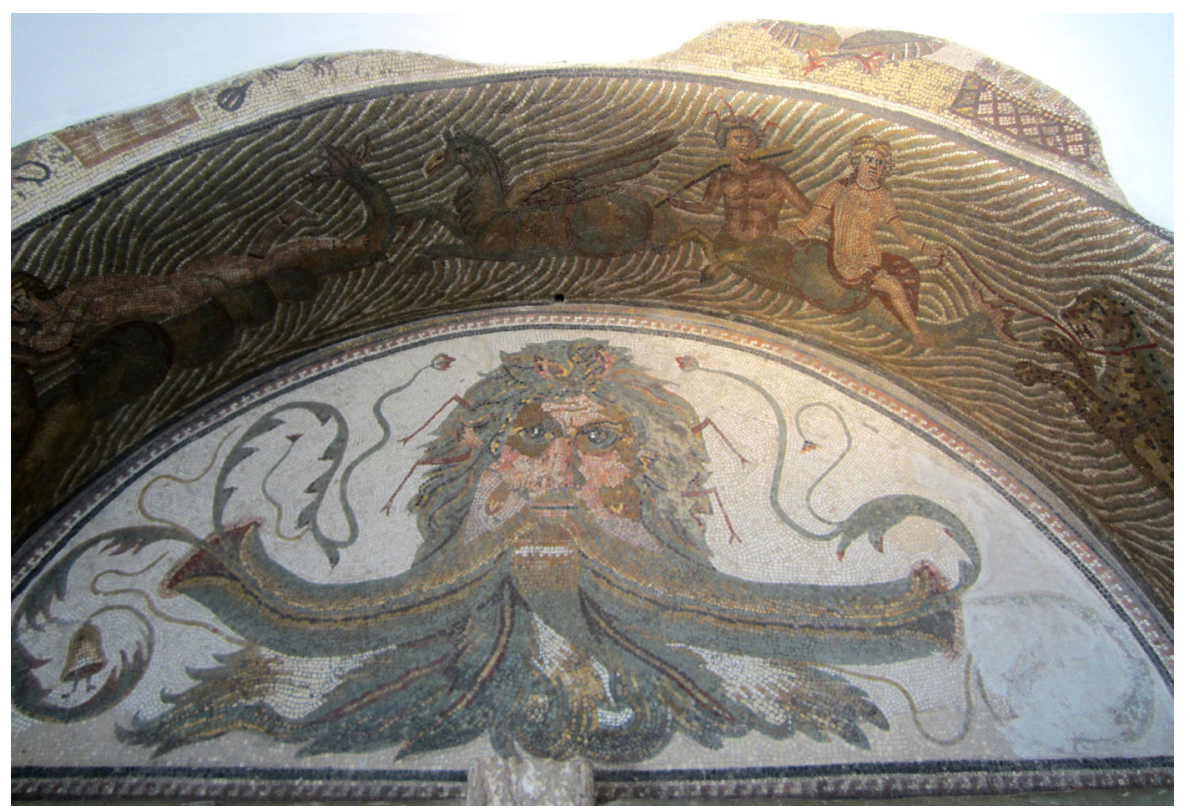

On the East side of the Mediterranean Sea, the craftsmen of the Levantine coast seem to have quickly specialised in another specific use of the foliate head: its insertion in a rinceau frieze. This pattern appears in the carved decoration of some public buildings of the $2^{\text {nd }}$ and $3^{\text {rd }}$ centuries $A D$, such as the so-called 'Bacchus temple' in Baalbek (Derwael in print: $n^{\circ}$ P A.Sy-R.2). Mosaicists seem to have paid the most attention to it.

From the second half of the $2^{\text {nd }}$ century AD this type of foliage was used in the borders of domestic pavements. It seems to have been favoured by craftsmen in the province of Syria, who used a relatively standardised composition (Fig. 8). The tendril is composed of acanthus and is usually set on a black background. Its rendering, more or less schematic depending on the style of representation, is naturalistic. Scenes of hunting or fruits occupy the scrolls, which are formed by the opposition between the leaves and plant windings forming a cornucopia. The foliate heads merge into the vegetal environment, through the homogenisation of their leaves' colours with the foliage. Bearded and beardless heads often coexist and are usually placed on an upside-down acanthus leaf (Fig. 9). The types of vegetalisations employed differ to a slight extent. The 'enveloping vegetalisation' is almost exclusively limited to oriental pavements: the heads are either enshrouded by the leaves of the foliage that make up the hair or are covered with a composition resembling a vegetalised helmet. Naturalistic hair constituted of short or long leaves, and a splayed or trifid beard are also widely used. Mosaic artists diversify this basic pattern by playing with the number of heads, their orientation and position, or by varying the motifs that people the scrolls. How did such a specific use of the foliate head develop?
Figure 7

Mosaic from the House of Bacchus and Ariadne, Thuburbo Majus. Photo: Stéphanie Derwael. 
Figure 8 Mosaic of a triclinium, Naplouse. Photo from Talgam - Weiss 2004: fig. 6.

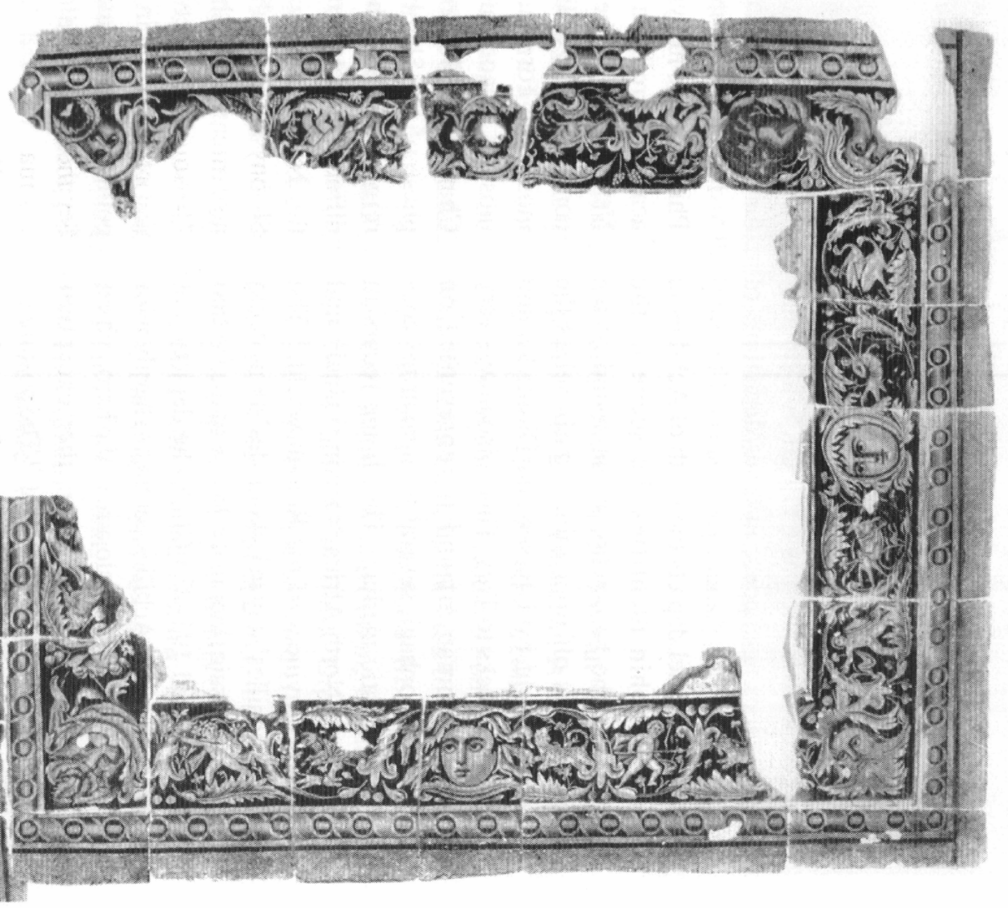

Figure 9 Mosaic of the House of Poseidon, Zeugma. Photo from Önal 2009: 40.

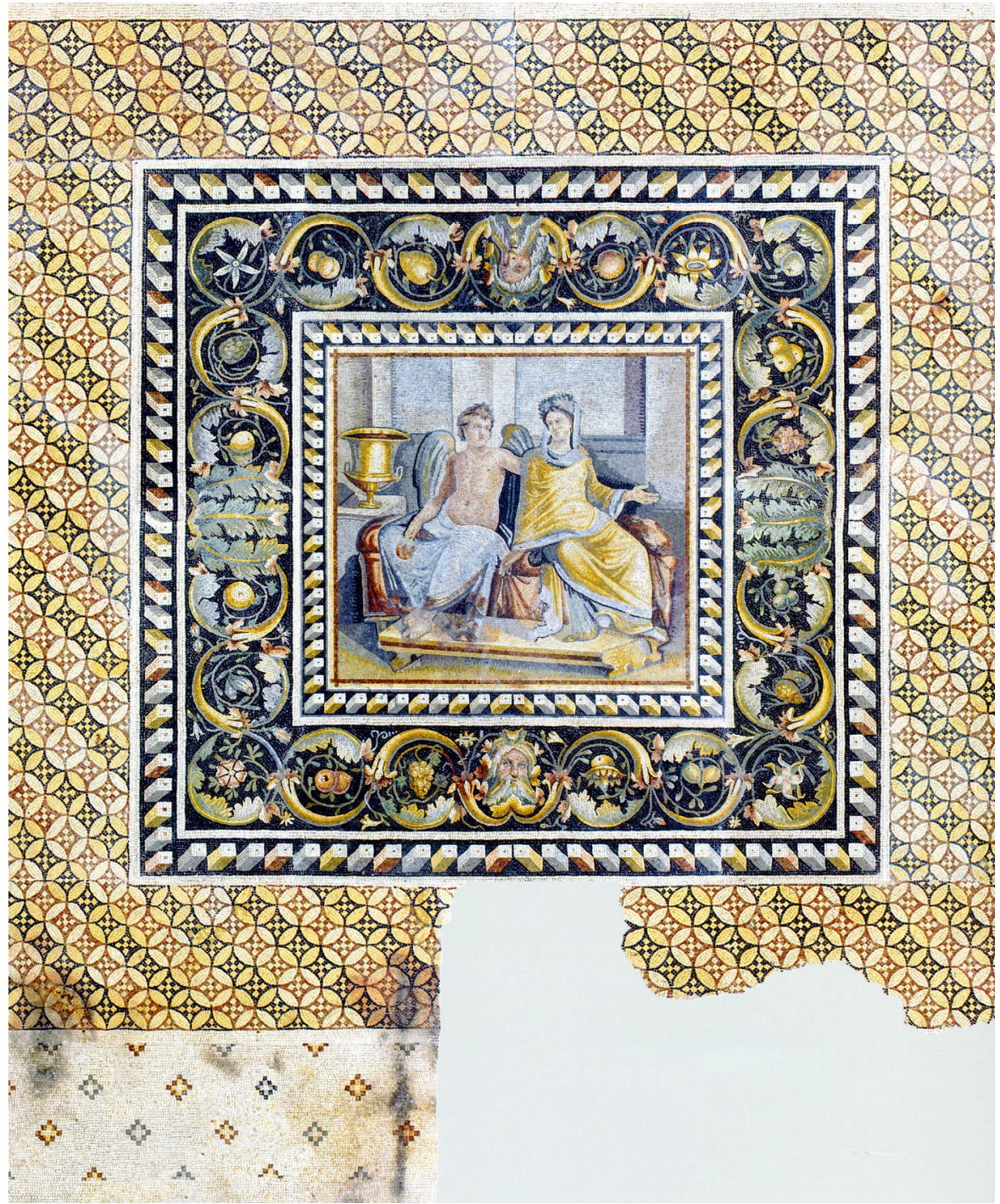


As early as the $2^{\text {nd }}$ century $\mathrm{AD}$, some cities in the Eastern Mediterranean acquired a new status and the rising elite adhered to the culture of their new social class, conforming to the aesthetic taste they thought attached to it. The pictorialising tradition inherited from the Hellenistic period is thus highlighted in the public rooms of rich houses where the local elites claim the continuity of a collective cultural heritage (Balty 1995: 148; Roe 1995: 30; Swift 2009: 4445; Bianchi Bandinelli 2010: 328-333). The central panels and borders of the pavements are the privileged witnesses of this. In this context, the illusionist foliate border on a black background appears as the transposition and adaptation of a Hellenistic pattern that enjoyed a certain success in the Late Republican and Imperial periods. The earliest known example of this pattern appears to be the frieze of the mosaic from the Palace $\mathrm{V}$ in Pergamon, dated to the middle of the $2^{\text {nd }}$ century BC (Fig. 10) (Toynbee - Ward Perkins 1950: 36; Coarelli - Sauron 1978: 717-719 fig. 28; Sauron 1978: 729-730). This frieze is characterised by the use of different shades of colour between the inner and outer surfaces of the plants, a trick that inscribed the scrolls in a three-dimensional illusionistic space.

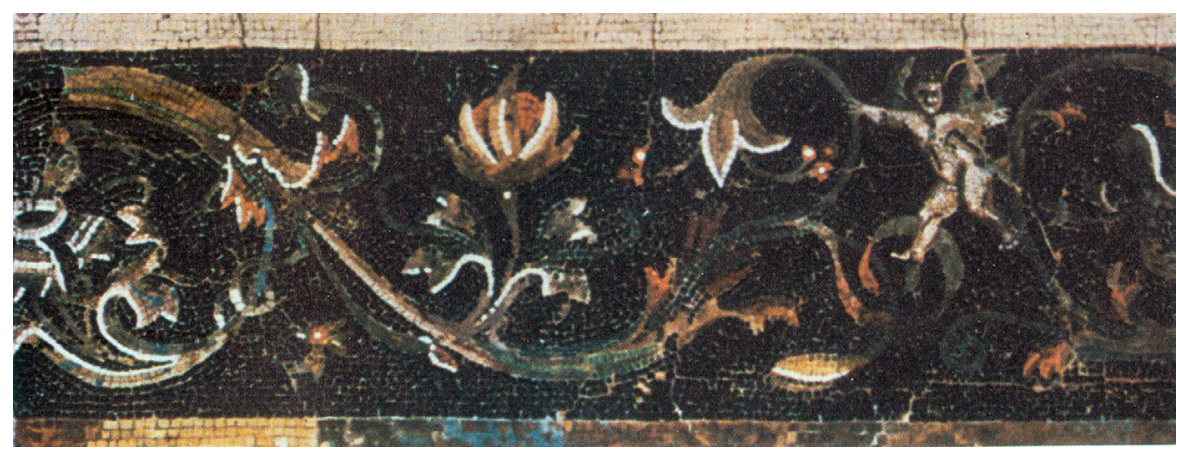

The foliate heads, by their insertion in this type of peopled scroll, a strong motif of the claimed Hellenistic tradition, become a key element of the repertoire of mosaicists. In the plastic field, they bear witness to the importance of Roman influence on the Eastern provinces, despite the strong local Greek identity. They are used in the domestic context, in the public rooms of rich houses where the luxury and culture of the local elites manifested themselves, elites who could have been truly Hellenised or just eager to display their wealth by following a trend (Balty 1995: 159). The panel around which the pavements of these houses are organised, are often taken from great painting. They function as 'owned and exhibited artworks' (Darmon 2008: 490) ${ }^{2}$ which manifest the cultural and material wealth of their owners and testify to their belonging to the social elite (Darmon 2008: 490-492). The mosaic of the triclinium of the Synaristôsai house in Zeugma (Derwael in print: $n^{\circ}$ Mo.Sy-D.2), for example, provides an illustration of the comedy 'Women lunching together' by Menander (Darmon 2011: 43). This painting is signed by Zôsimos of Samosata, a mosaicist active in Zeugma at the beginning of the $3^{\text {rd }}$ century AD (Darmon 2005). This certainly contributes to the value of this type of domestic art gallery (Darmon 2008: 490). In this corpus, paintings and borders are therefore part of the same claim to cultural heritage. However, apart from the affirmation of the social status of the owner in the most important rooms of his house, what message do these pavements, decorated with a border of foliage with foliate heads, convey?

Some pavements are organised around mythological scenes. In Homs (Derwael in print: $\mathrm{n}^{\circ}$ Mo.Sy-Ind.3), for example, the four paintings relate to the cycle
Figure 10

Mosaic of Palace V, Pergamon.

Photo from Coarelli - Sauron 1978: fig. 28.

2 « auvres d'art possédées et exposées ». 
of Heracles, the civilising hero, and reflect the taste of that time for the personification of abstract ideas (Abdallah 2011: 12). However, it is the hunting scenes that are the most frequent. Of course, they exalt the owner's comfortable lifestyle, but they generally also have a moral dimension (Aymard 1951: 319; Anderson 1985: 147; Badel 2009: 44-47). It is thus logical that the dangerous hunts, which mobilise audacity and courage, and are similar to real warlike fights, testify to this hunting virtus. Representations of feline, bear or wild boar hunts can thus be perceived as a form of heroism. They also represent the victory of order over chaos. On a mosaic in Palmyra (Fig. 11), the heroism of the figures takes place in a specific historical context. The acanthus border encloses two paintings depicting a horse archer killing two tigers, and Bellerophon defeating the Chimera. The Palmyrean cursive inscription Dydts 'bd // psps d'hw // wbnwhy MR, the last two letters of which designate the title 'Our Lord' worn by Odeinat and his son Herodian, links these scenes to the victory of the two rulers over the Persians between AD 260 and 267 (Gawlikowski 2005; Balty 2011a: 75). However, the most frequent hunting scene in our corpus is that of the Calydonian boar, perhaps due to the success of Euripides' play (Balty 1999: 75; Balty 2013: 214). The theme of Meleager and Atalanta is popular on late domestic pavements, where the episode often serves more as a self representation of the commissioner (Raeck 1992: 71-98; 1997; Balty 2013) than as an evocation of the mythological episode (Balty 1999: 76). On a mosaic in Sôran (Derwael in print: $\mathrm{n}^{\circ}$ Mo.Sy-D.10) dated to the $5^{\text {th }}$ century AD, the scene is situated, besides being mythical and tragic, in a specific domestic context: that of a rich estate whose dogs, horses, and staff are valued and identified by inscriptions (Balty 2013: 213-214). As is often the case, the border itself is furthermore decorated with hunting scenes that develop in the volutes of the scroll. It is then Erotes who chase the ferocious beasts.

Figure 11

Detail of a mosaic from Palmyra- Bellerophon defeating the Chimera. Photo from Gawlikowski 2005: fig. 4.

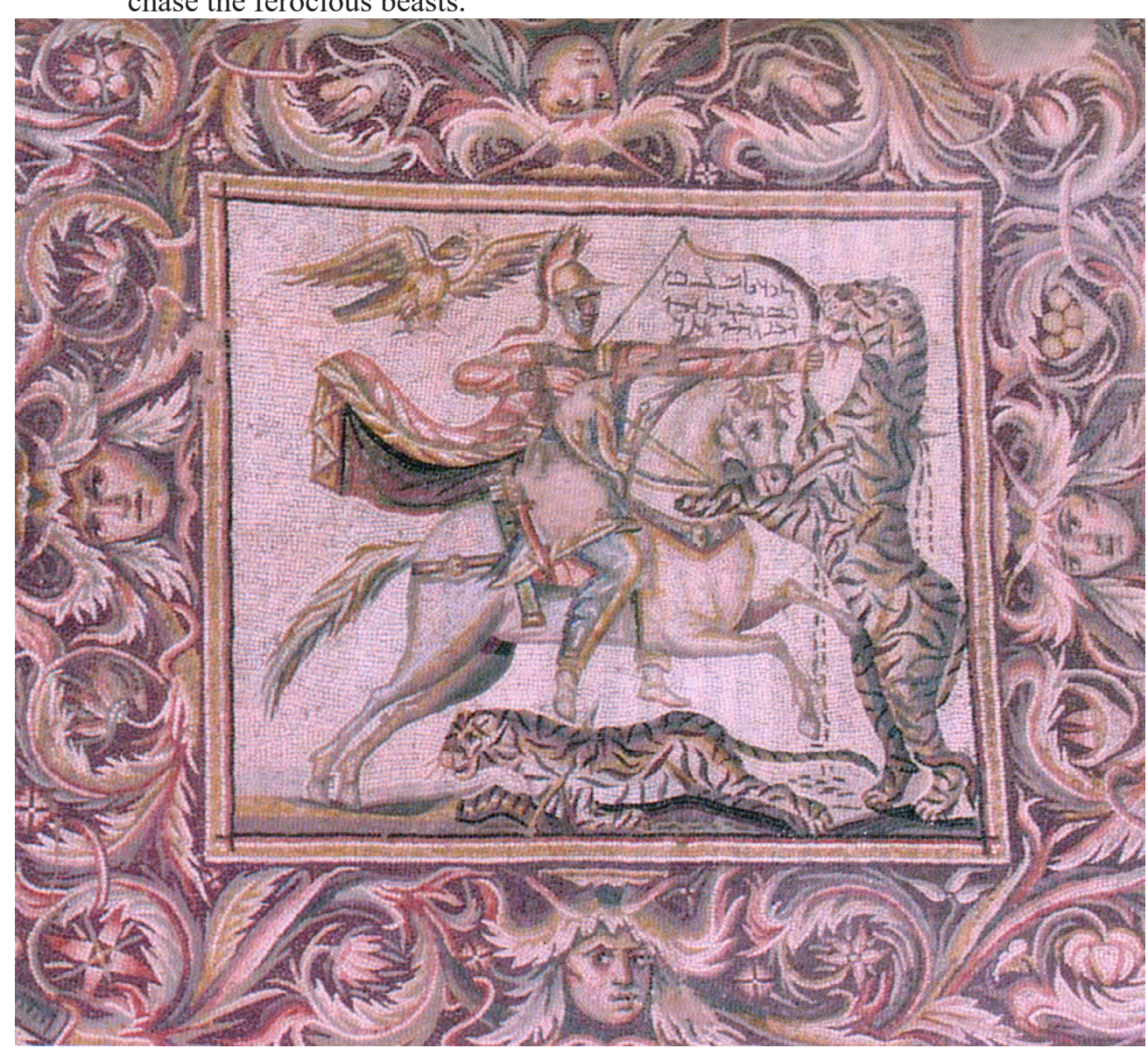


In the 'Seasons mosaic' of the Constantinian Villa at Daphne (Figs. 12-13), real and mythological hunting scenes are associated with the theme of abundance. The scroll is made of acanthus roots from which the figures of the Seasons, charged with their respective gifts, emerge. Vine sprouts, bunches of grapes, and golden tendrils decorate the acanthus here and there, while fruits and flowers fill the scrolls. The two preserved foliate heads are beardless here. The outer edge of the room is decorated with Virtues and pastoral scenes with banqueting Erotes, peasants making flowers garlands, or shepherds with their flocks.
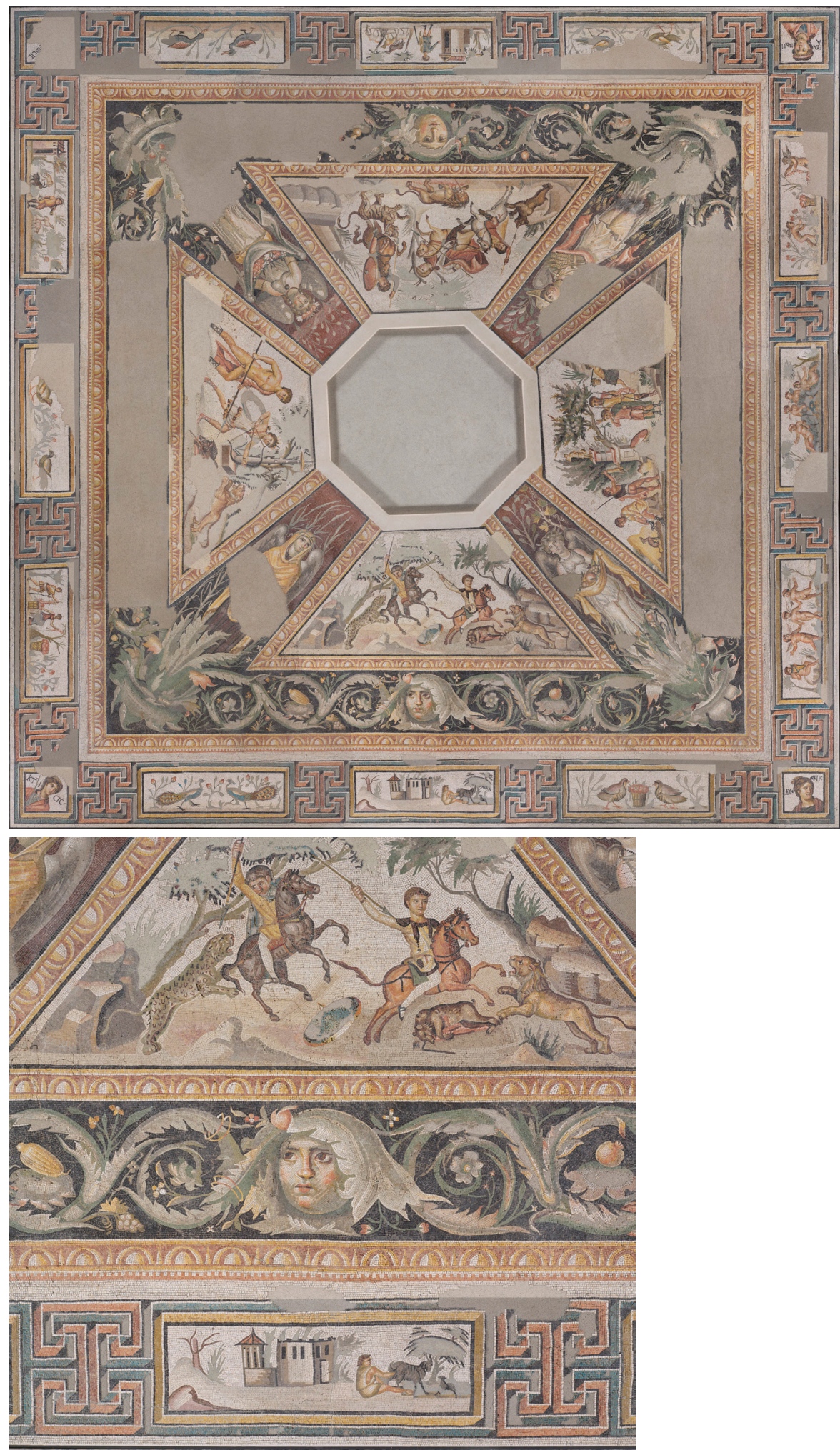

Figure 12

Mosaic of the Seasons, Constantinian Villa, Daphnè (C) Musée du Louvre (distr. RMNGP) / Hervé Lewandowski).
Figure 13

Detail of the border of the Mosaic of the Seasons, Constantinian Villa, Daphnè (C) Musée du Louvre (distr. RMN-GP) / Hervé Lewandowski). 
Finally, some pavements are exclusively centred on the theme of abundance and reflect a desire to attract and maintain inside the house the benefits of the earthly powers guarding fertility. Shahba's 'Plutos mosaic' (Fig. 14), dated c. AD 250 (Duchesne-Guillemin 1975: 107; Balty 1977: 24; Talgam - Weiss 2004: 109-110; Balty 2011b: 85$)^{3}$, glorifies an agrarian couple that can probably be identified with Opora, the force of summer, and Agros, the field (DuchesneGuillemin 1975: 106-109). Pluto, the Earth, and the Seasons complete the scene, identified by their names written in Greek capitals. A calathos, attribute of the fertility deities, caps Pluto and Gê, but also some of the foliate heads of the border ${ }^{4}$.

Figure 14

Mosaic of Plutos, Philippopolis. Photo from Balty 1991: pl. D.

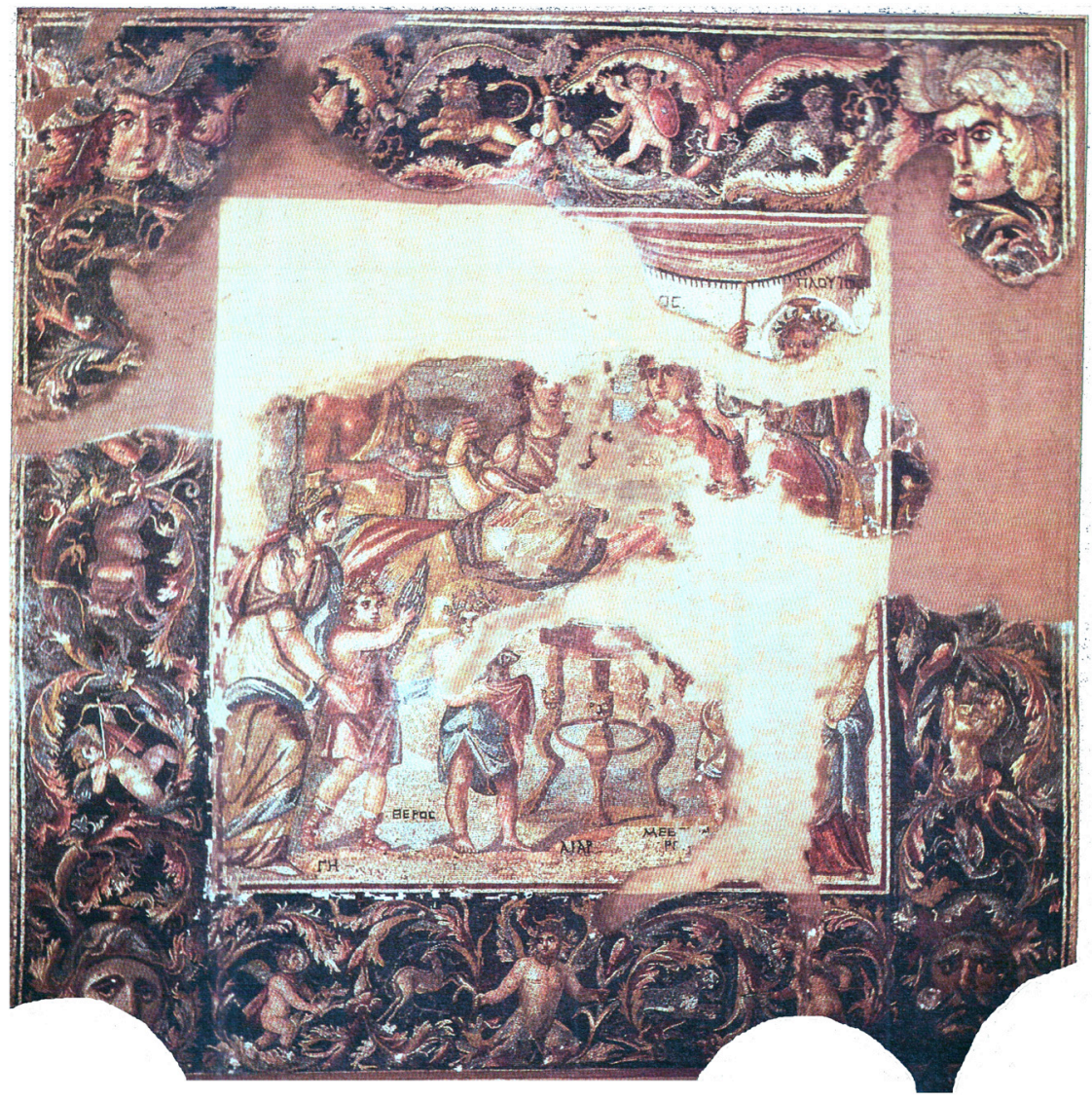

In this corpus of oriental mosaics, the rinceau border, which is part of a valorising reclaim of Hellenistic heritage, sometimes echoes the motifs of the central panel. The hunting scenes come to mind in particular. But the relationship does not always seem so explicit. Could it be a simple decorative fantasy? The acanthus scroll does not exist in reality; it is a creation of craftsmen of the Greek world. If its development corresponds to the flowering of ornamental values, it also seems to refer to the spontaneous, luxuriant, and even supernatural growth of vegetation. The acanthus, a weed that grows even in the most arid lands, appears to be a guarantee of rebirth, of the triumph of life over death (Gros 2010: 133). Its vital power manifests a form of hope, sustainability, and prosperity. The

3 The upper border may be evidence of a later repair. The leaves are thicker and less flexible than on the rest of the foliage. According to M. Duchesne-Guillemin, this difference can be explained either by the cooperation of two craftsmen on the mosaic or by an antique restoration of the pavement. J. Balty as well as R. Talgam and Z. Weiss follow the latter hypothesis. J. Balty first dates this restoration to c. AD 320, but then opts for a dating from the Tetrarchic period.

4 Unless it is an upside down cantharus. 
fruits, flowers and young sprouts that emerge from the foliage evoke the gifts of the Seasons and of a nature in constant renewal ${ }^{5}$. The vegetal windings that punctuate the grid of the foliage, a sort of chalice or corolla, form real horns of plenty. They thus evoke the opulence of the cornucopia, which concentrates all the seasonal wealth in them (Chappuis Sandoz 2004: 362-363). Flowers can also refer to the fragility of human destiny, as many ancient authors remind us by comparing the death of a person to that of a flower (Auger 1995; Chappuis Sandoz 2004: 102).

The scrolls, promptly associated to divine power (Castriota 1995: 58), give a superhuman dimension to the decorative program of the pavement, an add symbolic value along with the notions of prosperity and abundance, that derive from the owners' lifestyle, and ensure its continuity. However, the themes of the panels, whether civilising heroes, heroic hunts, pastoral, mythological, or interior scenes, also celebrate a virtuous and moderate way of living, a pious relationship with nature, and the benefits of civilisation, marking the victory of order over chaos. In Zeugma's 'mosaic of the Provinces' (Derwael in print: $\mathrm{n}^{\circ} \mathrm{Mo}$.Sy-Ind.2), the scroll border is part of a political and geographical allegory of the Empire (Parlasca 1983; Darmon 2008: 494-495), as Poseidon on a chariot appears as the cosmocrator of the Roman oikoumene, surrounded by busts representing the provinces. This pavement can thus be interpreted as a marker of adherence to the established order, and to Romanity. Order and virtue are the conditions for the prosperity celebrated by the scrolls.

In this context, what value can foliate heads have? From their appearance in the second half of the $1^{\text {st }}$ century $\mathrm{BC}$, the foliate heads, which are formally situated at the crossroads of the Roman monstra and the 'Masters of Vegetation' inherited from Greek culture, symbolise the mastery of a vital impulse. They celebrate a prosperous nature, feared but revered, a prodigious original nature made beneficial and calling for a rebirth. They can therefore evoke, and call for, an idyllic golden age. The fact that only a head is depicted, and not the whole body, is also meaningful. The Latin term caput refers to the human head, but it can sometimes also refer to the root of a plant, or the source of a river (Onians 1951: 125; Vadé 1977: 35). It symbolises the origin, the very essence of the vital impulse. The parallels established between the human and vegetal natures, and in particular between botanical growth and hair growth (Brulé 2008; King 2008; Brulé 2015), have long since invaded the mythical, cultural, semantic, literary, and medical fields (Forbes Irving 1990: 133-137; Aubriot 2001). Although the entirety of the body can be covered with hair, it is often the beard and hair that serve as a starting point for hairy demonstrations. In Roman society, as in the Greek world, the beard is a sign of masculinity (Gleason 1990: 400-401; 1995: 69; King 2008: 154-155). It is also a manifestation of sexual activity and an expression of the strength of age (Brulé 2015: 290). The absence of a beard therefore characterises both young men, and women (King 2008; Brulé 2015: 39-41).

The foliate beardless heads are, with few exceptions, a specific oriental feature. They are also found on the decoration of a contemporary box found in Haifa (Derwael in print: $\mathrm{n}^{\circ} \mathrm{O}$ Ap.J-F.1) and are therefore not limited to the repertoire of mosaicists. The alternation of the two types, bearded and beardless, could evoke the two genders, or refer to a form of natural cycle, to the succession of ages of life put in parallel with the seasons (Brulé 2008: 139-142; 2015: 8286). However, some have identified the beardless heads with the gorgoneion

5 Fruit, a gift of nature, could also evoke the goods offered to guests by the owner of the house. 
(Balty 2011b; 2016), and the bearded ones with Oceanus (Ovadiah - Turnheim 1997; Balty 2011b; 2016). It is true that the vegetal hybridity of the foliate heads serves as an 'iconographic epithet', as it is already the case for the 'Masters of Vegetation' inherited from the Greek world. It thus makes it possible to plastically translate a field of activity or an intrinsic quality of the represented person (Pensabene 2007: 256). Certain attributes or singular plants can then be used to identify Oceanus, Pan, or Jupiter Ammon. In the case of Oceanus, these are claws, antennae, or legs of crustaceans, marine animals, or seaweeds. In the corpus of oriental mosaics, however, Oceanus is always represented as a bust or a full figure, in the manner of river gods, wearing temporal crustacean claws and holding a rudder. Tethys accompanies him, his forehead encircled by a pair of wings, and escorted by Keitos ${ }^{6}$. In the rinceau borders, no foliate head bears such attributes, but formal influences may have occurred. On a pavement from Bithynia (Derwael in print: $n^{\circ}$ Mo.Bi-D.1), which follows the pattern of the scroll border from the Levantine coast, the heads have ears that are reminiscent of those of Western oceanic heads, and maritime motifs decorate the borders. This example attests to the malleability of the foliate head in the Eastern provinces. But this is an exception, and formal analogies do not necessarily imply the maintenance of a semantic content.

Some researchers link the foliate heads to the cult of Bacchus (Mendel 1914: 547; Mazza 1982: 23; Piccirillo 1986: 224; Ovadiah 2001: 4). It is true that the god presides over renewal and guarantees abundance. He is the one who is reborn with spring (Plut. De Is. et Os. 69; Him. or. III, 6). He is also at the origin of a new golden age in which nature does not have the borders of the ordered cosmos but helps to maintain cosmic order. The vital impulse, if not channelled, constitutes a danger to the order of the city, as much in its vegetal form, as in its erotic or Bacchic form (Gury 2014: 173). Bacchus embodies the mastery of this subversive nature. His prerogatives as a deity of vegetation have thus been represented, most likely since the beginning of the $4^{\text {th }}$ century BC, in the form of the Rankengott. As an agrarian god, he was also associated with Demeter in Eleusis as early as the $5^{\text {th }}$ century BC, the two deities being at the origin of the two gifts that constitute the condition of civilised culture (Pind. I. VII, 3-5; Moreux 1970: 6-12; Versnel 1990: 167-169; Isler-Kerenyi 2015: 245), wine and wheat. Could the alternation of bearded and beardless foliate heads in the borders of oriental pavements refer to such deities? Unless it serves to represent the different facets of the same deity, such as the Dionysos dimorphos, who Diodorus defines as "a double epiphany, bearded and beardless, of the same god" (Diod. IV, 5, 2; Turcan 1958: 2007)? In some borders, vine sprouts and bunches of grapes decorate the foliage, while golden tendrils surround it (Fig. 13). In the mosaic in Room 4 of the Constantinian Villa in Daphnè (Derwael in print: $\mathrm{n}^{\circ}$ Mo.Sy-D.5), foliate heads topped with a fine ivy tendril with corymbs even give rise to a vine scroll with birds, grape clusters, and grape-picking lovebirds. The Bacchic identification is therefore quite plausible. Bacchus is not only associated with vine and ivy, it can also be accompanied by the sole acanthus (Guimier-Sorbets 2004: 918-919). In Baalbek, the acanthus frieze with foliate heads decorates the so called 'Bacchus temple' (Derwael in print: $n^{\circ} \mathrm{P}$ A.Sy R.2). The question arises, however, as to whether it is always appropriate to speak of Bacchus' heads, or whether they are heads that refer more broadly to the world of the god and the prosperity that results from it.

Foliate heads of the oriental mosaic borders are part of the message conveyed

6 I.e.: mosaic of the Antioch "calendar house". 
by the scroll. They reinforce the general message of the pavement. The few examples found in Bithynia and Cyprus show that this pattern is not strictly limited to the Levantine coast, but also inspired mosaicists in other Eastern provinces. Figurative productions from the Eastern Mediterranean constantly enrich the Roman iconographic repertoire. Compositions such as the scroll with foliate heads spread to Italy and the West, where they were copied and renewed. Some pavements from North Africa, the Iberian Peninsula, and Italy, attest to this circulation of craftsmen and patterns. But these are exceptions. Although the workshops on the Levantine coast do not have exclusivity over the motif, they do make it a specific feature of their repertoire. In fact, while the use of the foliate head diminishes in the various regions of the Roman world from the $4^{\text {th }}$ century AD onwards, sculptors and mosaicists in the Eastern provinces continue to show a certain creativity, paving the way for a medieval usage of the motif, enriched by earlier experimentations.

In Judea and Arabia, mosaicists in charge of decorating Christian churches and funerary monuments of the $6^{\text {th }}$ century $\mathrm{AD}$ inherit the repertoire used by their predecessors in the domestic context. This revival corresponds to a resurgence of the classicising taste, which finds its climactic expression and diffusion at the time of Justinian. The pastoral, harvest, and hunting scenes, the Nilotic motifs, and the peopled foliage are all part of this context. The $6^{\text {th }}$ century AD corresponds to the blossoming of the Madaba school, from which originated most of the pavements of this period that incorporate foliate heads in their borders ${ }^{7}$ (Figs. 15-16) (Piccirillo 1984a-b; 1989a-c; 1995; 2002; 2003). The heads are bearded and beardless. They occupy the corners of an acanthus scroll on a black background, increasingly stylised, which acts as a geometrical vegetal grid. The mosaicists no longer seek to render depth and perspective and
Figure 15

Details of the mosaic of the Deacon Thomas Church. Photo from Piccirillo 2002: 186-187.
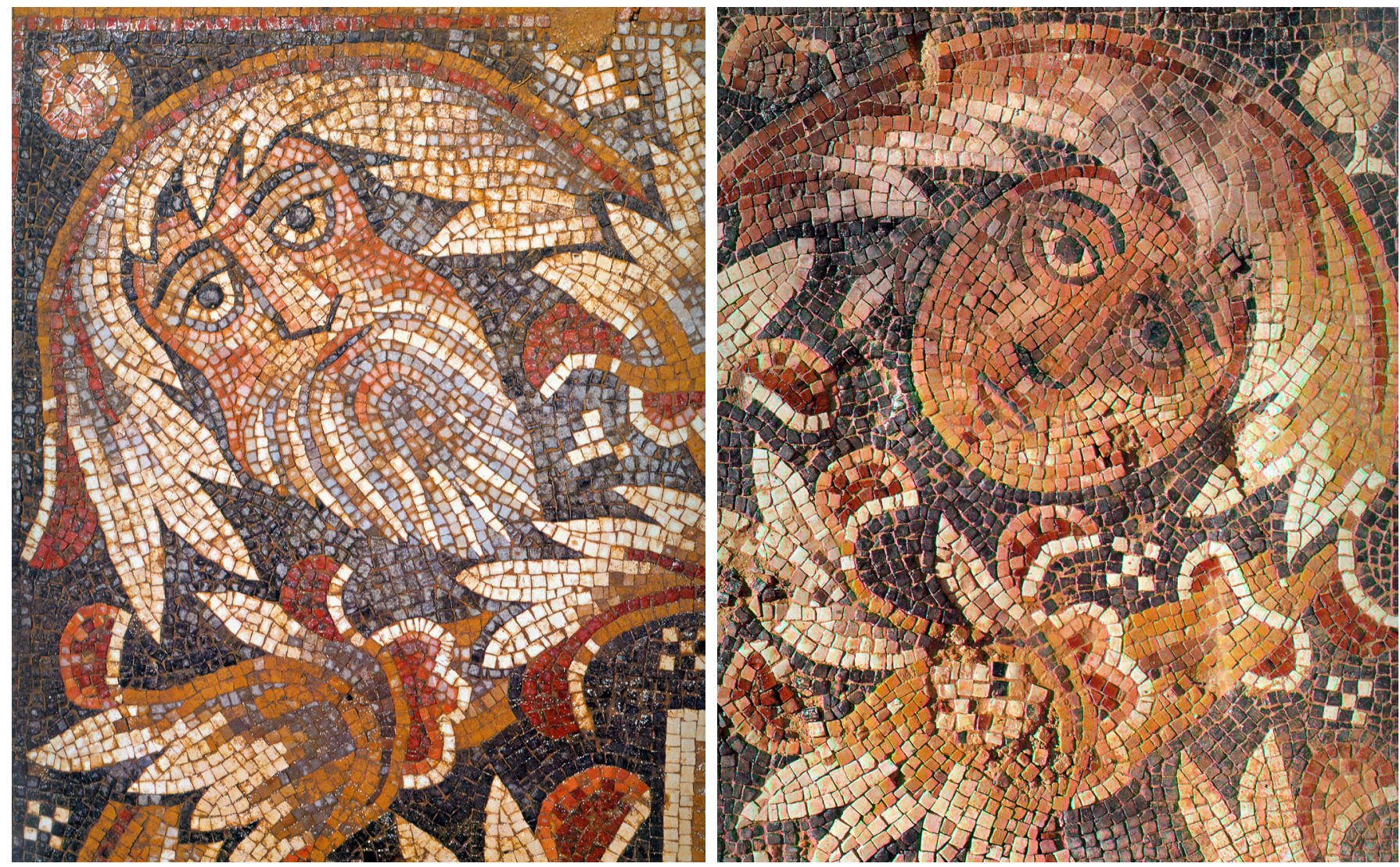

7 The Madaba school is active from the second half of the $5^{\text {th }}$ century AD until the Umayyad period. 
are no longer concerned with illusionism. The chromatic range is limited to a few colours, generally red, ochre, and green, but the craftsmen always ensure a certain homogeneity between the heads and the scrolls, although these latter are no longer spawning the heads. The vine occupies the centre of the pavement, on a white background, and forms volutes decorated with pastoral, hunting, or harvest scenes.

Figure 16

Orpheus Mosaic, Jerusalem. Photo from Cimok 2005: 210.

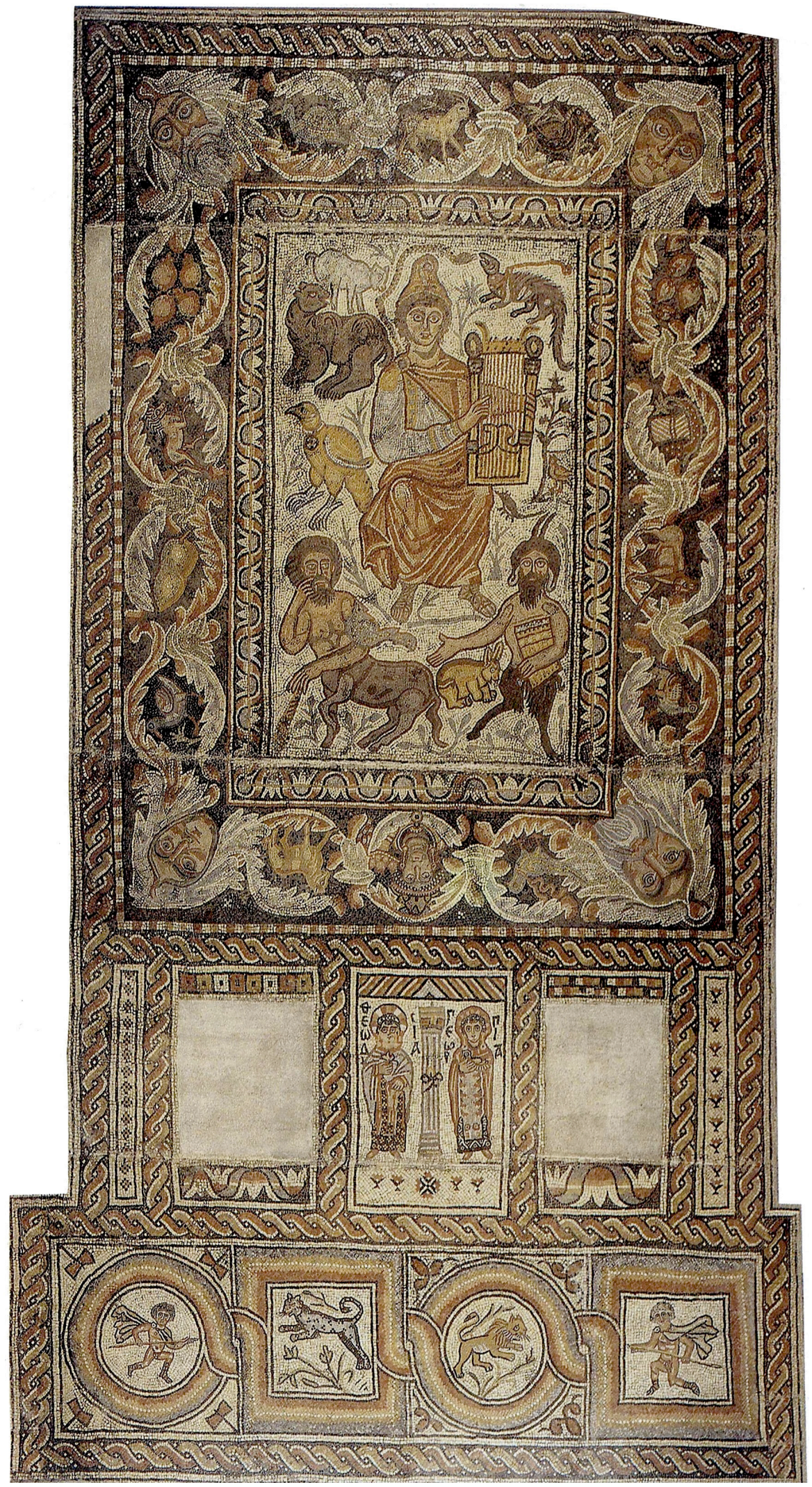


Although it has no apparent theological content, this repertoire is being reread in the light of biblical texts and Christian faith (Avi-Yonah 1936; Van Elderen 1970; Piccirillo 1982; Ovadiah 1984; Piccirillo 1984a-c; Ovadiah - Ovadiah 1987; Piccirillo 1989a-c; 1995; Hachlili 2009: 229). Scenes from daily life, animals, and fruit trees evoke the multiplicity of creation and suggest that God is visible through the things he has created. The scenes of hunting, or of the capture of wild animals, seem to refer to the idea of defence against hostile beings, which are naturally ferocious, but whose return, once tamed, will manifest the coming of the 'Peace of God' (Grabar 1963: 79; 1979: 53). As Saint Gregory the Great reminds the bishop of Marseille, the mosaic decorations contribute to the teaching of Christian doctrine for the faithful who cannot read (Lavagne 2000: 224). Motifs and syntax of the decoration echo the texts of the Bible and the gospel. The abstract nature of the decoration is often linked to the spiritual dimension of the decoration (Trilling 1989: 29). In this context, the foliate heads are presumably part of the celebration of God's power and goodness 8 .

During the $5^{\text {th }}$ and $6^{\text {th }}$ centuries $\mathrm{AD}$, the foliate head is also used in the repertoire of Eastern architectural sculpture. In the field of mosaics, workshops using the motif are almost exclusively located in the Levantine region, whereas in architectural sculpture the territory of present day Turkey seems to have the exclusivity. The motif is mainly used on capitals in the Bosphorus and its surroundings, especially in Constantinople ${ }^{9}$. Three main patterns are used for the integration of the motif: four heads develop around the circumference of a basket, where they alternate with a cornucopia emerging from acanthus leaves, loaded with fruits, and topped with a vine leaf (Fig. 17); two heads alternate with gorgoneia instead of abacus flowers, while busts of griffins act as volutes; or a single head unfolds on the front of a pilaster capital. This use of the motif is not new. During the $2^{\text {nd }}$ and $3^{\text {rd }}$ centuries AD, sculptors from the West coast of Asia Minor, and possibly even from Aphrodisias, were already using it in the decorations of public buildings in cities such as Ephesus, Hierapolis of Phrygia,
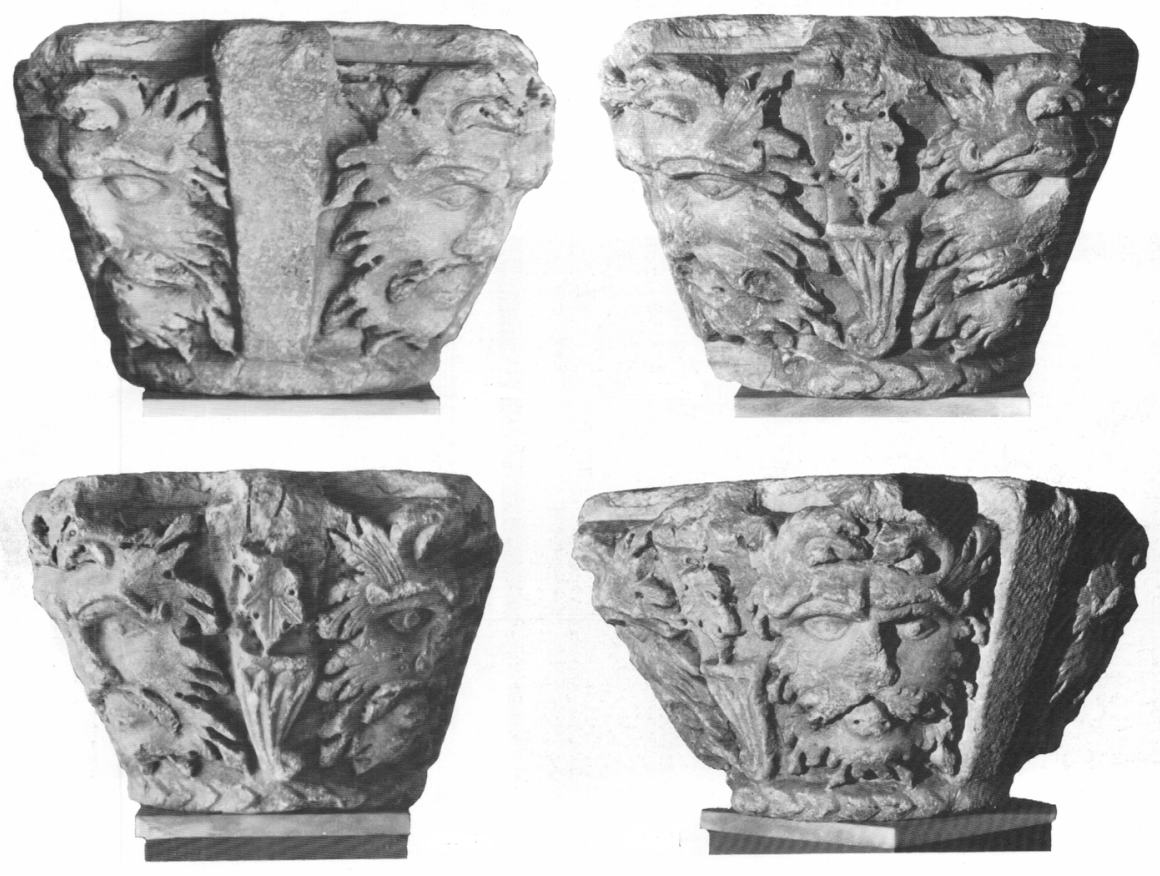

8 Some have seen representations of the Seasons or Rivers of Paradise.

9 The Constantinopolitan workshops exported their products to the Mediterranean, therefore spreading the capitals with foliate heads to Italy, Egypt, and Syria.
Figure 17

Capital from Değirmenkapı, Constantinople. Photo from Firatl1 1990: fig. 224. 

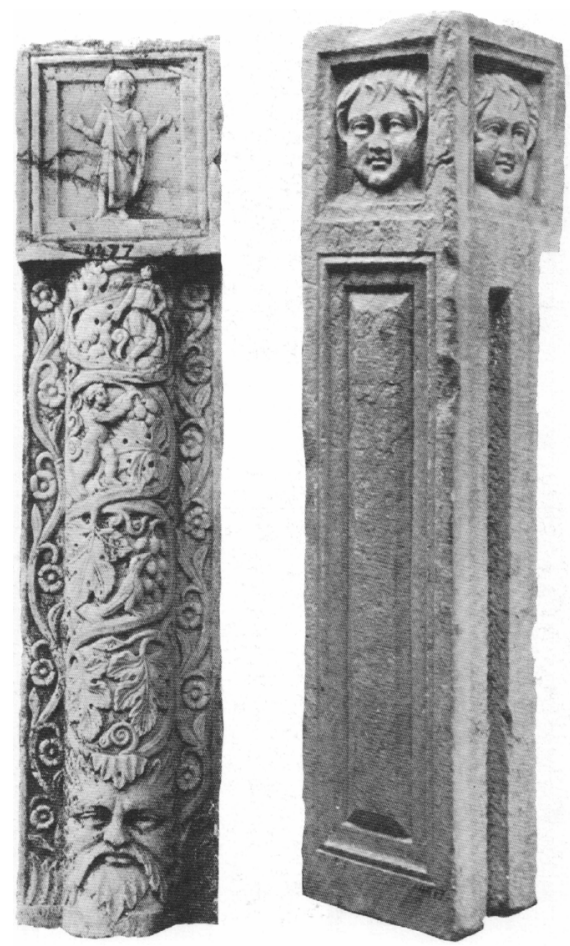

Figure 18

Parapet pilar from İzmit.

Photo from Firatl1 1990: fig. 290a-b. and Laodicea on the Lycus. However, the typology is different, as sculptors of the $5^{\text {th }}$ and $6^{\text {th }}$ centuries AD mainly use 'radiant vegetalisation'. The leaves circumscribe the face, forming a regular leafy pattern.

The intense production of capitals in Constantinople corresponds to the architectural renewal that has been ongoing in the city since the rule of Constantine (Betsch 1977) ${ }^{10}$. Until the middle of the $5^{\text {th }}$ century AD, many public monuments are erected, several for , and no less than fifty two colonnaded streets (Betsch 1977: 338-339) ${ }^{11}$. A large part of the local workshops' activity then consisted of producing capitals for these porticoes, which led to a search for simplification in the production chain and the implementation of the decorations. On Arcadius' column, which stands in the eponymous forum, the foliate head does not decorate the capital, but the frieze above the torus at the base (Derwael in print: $n^{\circ} \mathrm{P}-\mathrm{A}$.Th-HT.1). It develops into an acanthus scroll that resembles a mosaic border ${ }^{12}$. From the second half of the $5^{\text {th }}$ century AD, new buildings are mostly churches and their complexes. The cross on the rear side of a capital in the İstanbul Archaeological Museum (Derwael in print: ${ }^{\circ} \mathrm{P}-\mathrm{A}$.Th-Ind.1) shows that the motif could have been used in a Christian context, as is the case with mosaics from Judea and Arabia at the same time. The parapet pillars decorated with the motif (Fig. 18) probably belong to chancels or barriers separating naves in churches (Grabar 1963: 77-79; Firatl 1990: 140-141). The foliate head is located in the lower part, and spawns into a vine or acanthus scroll with harvest scenes, or animals eating grapes. A shepherd or an orant is added to the composition. The portraits in the upper part of the pillars may represent donors, who would have given these pillars as offerings to churches (Grabar 1963: 77), as is the case with the portraits inserted in the mosaics of these same buildings. The heads show a radiant vegetalisation, as on the Constantinopolitan capitals, or are topped by the leaves of the foliage, as on the mosaics.

At the end of this panorama of foliate heads of the Eastern provinces, it is time to return to the Great Palace of Constantinople. The mosaic of the peristyle (Figs. 3-6) is the culminating, but also the most controversial, document of the corpus of foliate heads in the Roman world. It is controversial, particularly because of its dating. The discoverers of the pavement suggest that it should be dated to the beginning of the $5^{\text {th }}$ century $\mathrm{AD}$, as it is not stylistically compatible with a later date. The reign of Theodosius II (408-450) seemed the most appropriate, as the emperor was considered to be a patron of the arts (Brett et al. 1947: 91-97). The elegance of the forms and the naturalism of the motifs give this mosaic a classicising character which has often led to a high dating. This point of view reflects an outdated perception of Late Antique and Early Byzantine art, according to which classicism did not survive long (Nordhagen 1963: 53-54).

Stratigraphic examination of the area allows this point of view to be put into perspective, and the dating of the pavement to be further clarified (Bardill 2006: 12-20; Westbrook 2019: 222-223). Several structures have been identified in the terrace level under the peristyle: a collapsed brick wall incorporating a 'Phocean red slip 3F' ceramic fragment, a type not found before AD 500 (Bardill - Hayes 2002); a two-storey structure made of bricks from the $4^{\text {th }}$ and early $6^{\text {th }}$ centuries $\mathrm{AD}$; and under the south-eastern portico, a cistern made of bricks stamped with a

10 According to W. E. Betsch, the formal evolution of these capitals reflects four main phases, each corresponding to a particular 'dynastic design': the Constantinian period (324-379), the Theodosian period (379-457), the Leonian period (457-518) and the early Justinian period (518-550).

11 This is considerable, as Eastern Mediterranean cities generally have no more than two or three.

12 The opposition between the leaves and the cornucopia-shaped plant scrolls determines the volutes. 
cruciform monogram not found before AD 518 (Bardill 2004). The peristyle and the colonnade are built on this terrace. The ground level is then raised somewhat, the colonnade redone, and the mosaic installed. The mosaic is later covered with a marble slab paving, which explains its good preservation. Finally, pottery and coins dated at the latest to c. AD 700 were found in a trench dated from after the laying of the marble slabs. If these finds correspond to the trench, the paving should not be posterior to this date. Just below the mosaic, an insulating layer consisting of stones and numerous terracotta fragments was also uncovered (Turnovsky 1992; 1999; Jobst 2006: 11). These shards belong to amphorae from Gaza, used in Constantinople from the second half of the $5^{\text {th }}$ century AD, North African amphorae in the form of KEAY LXIIQ and LXIIA, used until the $6^{\text {th }}$ century AD, Late Roman 1 and Late Roman 3 amphorae produced at the end of the $5^{\text {th }}$ and beginning of the $6^{\text {th }}$ century $\mathrm{AD}$, as well as fine ceramics of the Late Roman $\mathrm{C}$ and African sigillata types dated AD 460-475. In addition, no fragments of Late Roman 2 amphorae, which appeared in Constantinople from the second half of the $6^{\text {th }}$ century $\mathrm{AD}$, and of 'spatheia' from the $6^{\text {th }}$ and $7^{\text {th }}$ centuries $\mathrm{AD}$, have been found. Based on these elements, the mosaic is today legitimately dated to the reign of Justinian I (AD 527-565) (Jobst et al. 1997: 5861; Parrish 2005; Jobst 2006), and possibly even to the 530s. Indeed, the emperor is the initiator of numerous renovation and construction works in Constantinople following Nika's uprising in AD 532.

J. Bardill suggests dating the pavement to the end of the 6th century AD or even to the beginning of the $7^{\text {th }}$ century AD. The stamps on the bricks found below the level of the mosaic indicate, according to him, a possible post Justinianic date (Bardill 2006; Dark 2007). He attributes the peristyle to the reign of Mauritius, while the mosaic, which would have replaced the original floor of the peristyle, would date from the reign of Mauritius (582-602), Phocas (602-610), or Heraclius (610-641). It would thus predate the period when the large-scale construction of the city came to a halt. Some researchers agree, for their part, with the stylistic dating of J. Trilling, who dates the mosaic from around AD 630, during the reign of Heraclius (Trilling 1989; Dark 2007). Indeed, he recognises a predominance of North African models dating back to the High Empire in the various motifs preserved, an influence which he believes can be explained by the African origin of the emperor. However, only fifteen percent of the pavement is preserved today, and many of the motifs have clear parallels with Late Antique mosaics from the Eastern Mediterranean, particularly in the province of Syria (Hellenkemper Salies 1987; Parrish 2005). The mosaic appears moreover as a concentrate of Graeco Roman classicism, marked by the revival of iconographic forms and scenes (Hellenkemper Salies 1987; Parrish 2005; 2006; Jobst 2006). The omnipresence of historical quotations is typical of the Late Antique and Early Byzantine period ${ }^{13}$. Therefore, the revival of older iconographic themes does not, in any way, constitute an argument for dating.

'Late Antique', 'Early Byzantine', the period itself does not facilitate the dating of decorations. The $5^{\text {th }}, 6^{\text {th }}$, and $7^{\text {th }}$ centuries $\mathrm{AD}$ form a period of intense change. However, a period in the making is not a break with the past, but rather a simultaneous recourse to several cultural trends which, once confronted, create favourable grounds for change (Golsenne 2012: 17). Late Antiquity is thus characterised by the gradual intertwining of Roman, Christian, and 'barbarian' traditions. Opinions differ as to the chronology of Late Antiquity, depending on the criteria used (Inglebert 2006), but its end is generally thought to have been

13 See the works of Weitzmann, Kitzinger, or Nordhagen. 
around the $6^{\text {th }}-7^{\text {th }}$ centuries AD. From an artistic point of view, the $5^{\text {th }}$ and $6^{\text {th }}$ centuries $\mathrm{AD}$ generally serve as a transitional period, the reign of Justinian (527565), constituting its 'Golden Age' and appearing, according to A. Grabar, as "an essential stage" between the ancient and medieval traditions (Grabar 1966).

Exceptional in more than one respect, the Great Palace mosaic is struggling to find its place in art history due to the lack of archaeological data enabling its dating, and the absence of satisfactory comparisons in terms of quality of execution, decorative program, and dimensions. As J. Trilling points out, "instead of being accepted as a central monument, a touchstone of Byzantine taste, it is treated as an anomaly" (Trilling 1989: 28). In order to really understand this pavement, it must be understood for what it is: a Late Antique floor mosaic, of very high technical quality, made to decorate an official area of the imperial palace of the capital of the Eastern Roman Empire, and consisting of a juxtaposition of motifs and scenes from the Graeco Roman heritage.

But the very function of the piece that the mosaic decorates is a subject of debate. The peristyle is adjacent to a hall with an apse, a frequent configuration in palaces and villas of Late Antiquity (Nordhagen 1963: 65; Parrish 2005: 1104; Bardill 2006: 20; Jobst 2006: 7-8; Westbrook 2019: 51-88). These two structures are considered to be contemporary. In the tradition of the Roman peristyle house and palatial villas, this ensemble must have had a public function. It may have been an audience hall or a ceremonial space where the emperor would have received acclaim from dignitaries, the army, or other groups. Perhaps the Augusteus mentioned in the Book of Ceremonies ${ }^{14}$ is to be found there, unless it was an area that was no longer used for ceremonies by the $10^{\text {th }}$ century $\mathrm{AD}$ (Bardill 2006).

The form and function of the peristyle determine the structure and message of the decor. There is no need to apprehend the composition in its entirety or in a specific direction, and therefore no need to move along the peristyle to perceive its logic (Trilling 1989: 68; Jobst 2006: 17-18). The motifs move freely on an even, neutral background, offering what W. Jobst describes as a polyperspectived structure, a structure which is associated with the long tradition of landscape representations practised since the Augustan period (Jobst 2006: 17-18). This pavement could evoke an imperial garden in the Constantinople region, in the tradition of the ancient paradeisos, with the addition of some fantastic elements (Parrish 2006). But the combination of rural, violent, and mythological scenes seems rather to symbolise a prosperous empire in peace, a new golden age. The hunting and fighting scenes represent the victory of order over chaos. Motifs such as the eagle killing the snake (Fig. 19) are symbols of victory and protection (Brett 1942: 41; Kellum 1994: 31). The detail of the elephant, an animal formerly linked to the Concordia (Kellum 1994: 31), is also worth mentioning. The glorification of rural life is for its part reminiscent of the golden age transmitted by Virgil in his Georgics (Trilling 1989): peace and stability reigning in the countryside, and work and respect for nature generating prosperity and constant renewal. Bucolic literature from the Augustan period is still read in Late Antiquity, and knowledge of Virgil is attested to as far back as the $6^{\text {th }}$ century AD (Trilling 1989: 61-63; Soler 2019). Following Augustus, each emperor's reign is furthermore presented as a new golden age. This concept is still valid in Late Antiquity, especially since Augustus is considered to be the instrument of the divine will, as his reign of peace made the spread of Christianity possible (Trilling 1989: 61).

14 Protocol of the ceremonies held in the palace written during the $10^{\text {th }}$ century AD under Constantine VII Porphyrogenetus. 


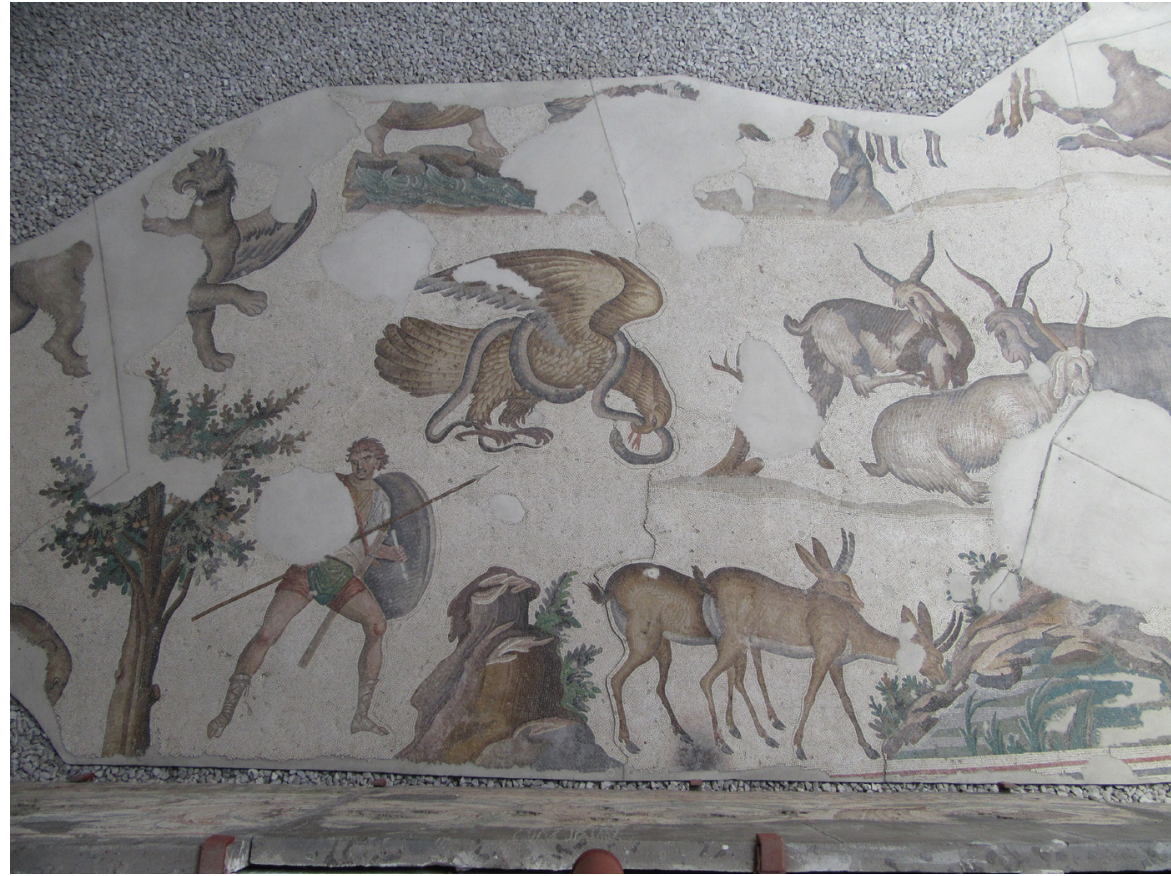

In the context of an imperial palace in the capital, the choice of the symbolic program for the Great Palace mosaic is therefore easily explained. The purpose of this floor is certainly to convey the image of the world over which the emperor reigns. A world torn between violence and ferocity on the one hand, and a peaceful and generous nature on the other, a dichotomy implying that one must fight for order and tranquillity (Dunbabin 1999: 235). The hunting theme is often used in this type of hall preceded by a peristyle, as are references to the Bacchic world (Parrish 2005: 1104). The aim is to celebrate a prosperous way of life, but also the benefits attached to it, illustrated by scenes from daily life and allusions to the peasant world, through the simplicity of rural life. Nature and landscape govern the iconography, expressing an idealised landscape, an imperial vivarium and a royal garden (Jobst et al. 1997: 56). They evoke, by metonymy, an idyllic empire to which the emperor brings peace and prosperity.

This pavement reflects the tastes and values of an elite whose education and lifestyle are still imbued with the thought system of the Antiquity (Parrish 2005: 1117; 2006). The mosaicists juxtapose themes specific to this cultured environment, drawn here and there from the arts, literature, or the model of contemporary royal gardens, and assemble them in a composition of unprecedented size, which testifies to their ability to juggle with motifs of secular origin (Dunbabin 1999: 235; Parrish 2006).

The pavement is also exceptional when compared to other mosaics in the city, which do not seem to attest to the presence of flourishing mosaic workshops (Dunbabin 1999: 232) ${ }^{15}$. Thematic and stylistic parallels, however, abound throughout the Mediterranean, not only in the field of mosaics but also in silverware and textiles, and it is known that craftsmen from all over the Empire flocked to Constantinople from the time of its foundation (Talbot Rice 1958: 148; Dunbabin 1999: 233-234; Parrish 2005; 2006: 593-594). The most eloquent parallels are to be found in the rural, bucolic, and hunting scenes, which flourish in the repertoire of mosaicists from the Eastern provinces. The border with
Figure 19

Detail of the Great Palace Mosaic, Constantinople. Photo: Stéphanie Derwael.

15 A production of sumptuous opus sectile pavements nevertheless exists in Constantinople: Guiglia Guidobaldi 2011. 
foliate heads has never really been considered in the analysis of the pavement's pictorial references. However, it is also part of a formal corpus which offers many points of comparison and helps in the general interpretation of the iconographic program.

In Constantinople itself, architectural sculpture offers precise parallels, where radiant foliate heads, combined with a peopled scroll or leafy cornucopia, can be found. These sculptures, and the mosaic, date from the $6^{\text {th }}$ century AD and seem to reflect a period of renewed interest in the motif. This type of border also appears in Christian pavements of the Levantine coast at the same time. The typology of these heads is identical to that of the two types of heads in the Great Palace: radiant vegetalisation, and heads inscribed in a scroll. Examination of the corpus of earlier Levantine pavements from the $2^{\text {nd }}, 3^{\text {rd }}$, and $4^{\text {th }}$ centuries $\mathrm{AD}$ shows that this type of border was already associated with various scenes emphasising prosperity, the victory of order over chaos, and a virtuous life. Similarly, the use of the motif in the imperial sphere is not new, and Arcadius' column offers a Constantinopolitan example of this ${ }^{16}$.

Within this vast corpus of foliate heads, there is one example that constitutes a particularly interesting point of comparison: the House of the Falconer in Argos (Akerström-Hougen 1974). The mosaics 'of the lion fight', 'of the hawk hunt' (Fig. 20), and 'of the months' date from the early $6^{\text {th }}$ century AD and decorate the room to the south east of the building, and the west and south porticoes of the courtyard, respectively. The elongated arrangement of the porticoes and the variety of scenes framed by the border are particularly noteworthy, although they are pictured on isolated panels and not on an even background like in Constantinople. The scrolls, although very stylised in Argos, are also identical: flowers, fruits, and hunting animals are here assorted with lizards, snakes, or even a turtle.

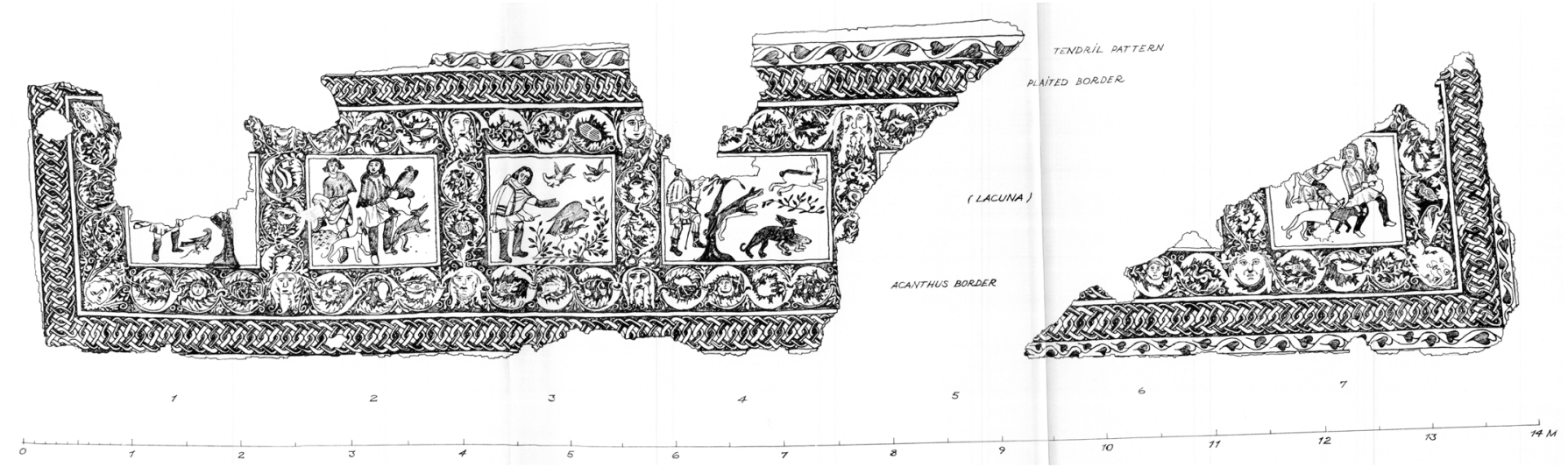

Figure 20

Mosaic of the Hawk Hunt, House of the Falconer, Argos. Drawing from AkerströmHougen 1974: pl. IV.
As demonstrated by D. Castriota, this type of polycarpophoric (a mixture of several plant species) and polytheriotrophic (a mixture of several animal species) rinceau, inherited from the Attalid Pergamon, had great success in the Roman world, and was even used on a key monument of the imperial propaganda, the Ara Pacis Augustae (Castriota 1995). It is a metonymic allusion to the divine, expressing a concord (homonoia). The border of the mosaics evokes an eternal golden age and includes the topical elements of abundance. The colours of the scroll - green, blue, gold, and purple - could moreover evoke the four seasons. In the Great Palace, the detail of the open flower on which cherries seem to

16 See also the Arch of Septimius Severus in Rome, a statue of Trajan of Gabies, or Nero's Domus Aurea for earlier examples. 
be offered up for tasting, illustrates a generous nature offering men all its gifts (Fig. 21). The symmetry and regularity of the composition express the order and mastery of a nature that has been made beneficial. The small animals and insects that populate the acanthus are symbols of fertility and apotropaic motifs that represent a fragile but balanced ecology, where animals live alongside fellow creatures, fruits, or insects, in harmony instead of eating them (Kellum 1994: 34-37).

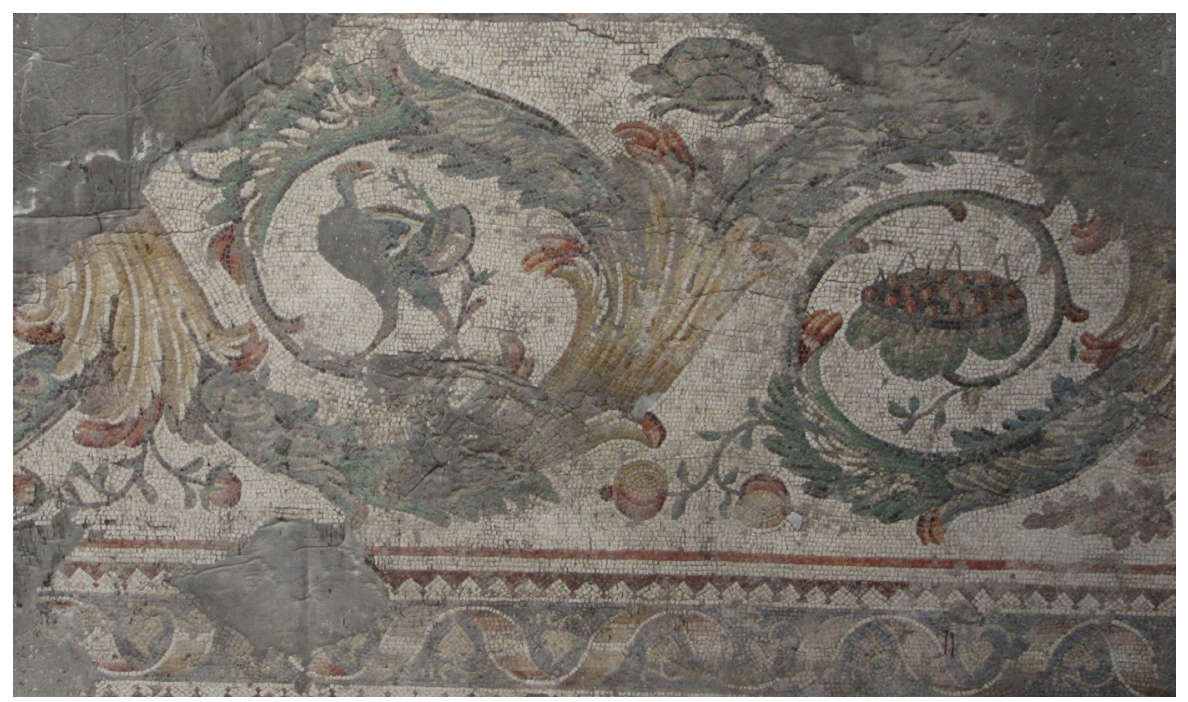

In his analysis of the scrolls, D. Castriota also identifies the theonomous tendril (Castriota 1995: 58-586), where deities in action evolve. This presence is embodied here by the foliate heads. In any case, an examination of the foliate heads of the Roman world puts D. Talbot Rice's 1958 description of the motif into perspective. In this Constantinopolitan context, the heads, although impressive for the delicacy of their execution and the liveliness of their features, probably do not constitute a more important motif than the foliage that hosts them, or the animals, flowers, and fruits in the volutes. The absence of aquatic elements encourages the rejection of their oceanic identification. The physiognomy of the heads with the large moustache seems to be the result different hands, as the size of the pavement necessarily implies the collaboration of several mosaicists on the border alone. The meanings that the foliate heads of the Roman world may have assumed do not fit well with the notion of portraiture, and it is difficult to see how representing 'barbarians' in a hybrid form would serve the general message of the pavement. As with the corpus of late Levantine pavements, however, it is difficult to give them a precise identification. But is it necessary?

The mosaic of the Great Palace in Constantinople is the product of an era and an environment whose tastes and values it reflects, offering a rich synthesis of Mediterranean artistic trends. Whether it is the border or the central panel, this pavement, which is at the crossroads of Eastern and Western influences, appears as the vector of a classical tradition in a context of claiming the ancient culture and heritage of the Roman Empire. In such a program, the use of foliate heads is significant. While their hybridity can certainly reinforce the message of prosperity and idyllic harmony conveyed by the central panel, they appear more as a strong motif of peopled scrolls, and thus of this ancient cultural tradition which is valued here. They are part of a repertoire considered as representative of Roman iconography by the Byzantine craftsmen of an imperial workshop.
Figure 21

Detail of the border of the Great Palace Mosaic, Constantinople.

Photo: Stéphanie Derwael. 


\section{Bibliography - Kaynaklar}

Abdallah 2011

Akerström-Hougen 1974

Anderson 1985

Aubriot 2001

Auger 1995

Avi-Yonah 1936

Aymard 1951

Badel 2009

Balty 1977

Balty 1991

Balty 1995

Balty 1999

Balty 2011a

Balty 2011b

Balty 2013

Balty 2016

Bardill 2004

Bardill 2006

Bardill - Hayes 2002

Betsch 1977

Bianchi Bandinelli 2010 (1970) R. Bianchi Bandinelli, Rome. La fin de l'art antique. L'art de l'Empire romain de Septime Sévère à Théodose Ier, (1970) Paris.

Brett 1942

Brett et al. 1947

Brulé 2008

Brulé 2015

K. Abdallah, "Mosaïque d'Héraclès découverte à Homs (Syrie centrale)", M. Şahin (ed.), $11^{\text {th }}$ International Colloquium on Ancient Mosaics, Bursa, 1-13.

G. Akerström-Hougen, The Calendar Mosaics of the Villa of the Falconer in Argos. A Study in Early Byzantine Iconography, Stockholm.

J. K. Anderson, Hunting in the Ancient World, Berkeley.

D. Aubriot, "L'homme-végétal : métamorphose, symbole, métaphore", V. Pirenne-Delforge - E. Delruelle (eds.), Kñ $\pi$ ot. De la religion à la philosophie. Mélanges offerts à André Motte, Kernos Supplément, 11, Liège, 51-62.

D. Auger, “A l'ombre des jeunes garçons en fleurs", D. Auger (ed.), Enfants et enfances dans les mythologies. Actes du VIIe colloque du Centre de Recherches Mythologiques de l'Université de Paris-X, Paris, 77-101.

M. Avi-Yonah, "Mosaic Pavements at El Hammam, Beisan”, QDAP V, 11-30.

J. Aymard, Essai sur les chasses romaines des origines à la fin du siècle des Antonins, Paris.

C. Badel, "La noblesse romaine et la chasse", J. Trinquier - C. Vendries (dir.), Chasses antiques : pratiques et représentations dans le monde gréco-romain ( $\mathrm{III}^{\mathrm{e}} \mathrm{s}$. av. - IV ${ }^{\mathrm{e}} \mathrm{s}$. apr. J.-C.) : actes du colloque international de Rennes, Rennes, 37-51.

J. Balty, Mosaïques antiques de Syrie, Bruxelles.

J. Balty, "Les mosaïques du musée de Suweida", J.-M. Dentzer - J. Dentzer-Feydy (eds.), Le djebel al-Arab. Histoire et Patrimoine au musée de Suweida, Paris, 81-84.

J. Balty, Mosaïques antiques du Proche-Orient. Chronologie, iconographie, interprétation, Centre de Recherches d'Histoire Ancienne, 140, Paris.

J. Balty, "Un propriétaire d'Apamène au Ve siècle", dans N. Blanc - A. Buisson (eds.), Imago Antiquitatis. Religions et iconographie du monde romain. Mélanges offerts à Robert Turcan, Paris, 73-80.

J. Balty, "La mosaïque romaine au Proche-Orient. Nouveaux documents", DossAParis 346, 72-77.

J. Balty, "Le rinceau d'acanthe à fond noir dans la mosaïque syrienne : l'exemple de Mariamin”, H. Meyza - I. Zych (eds.), Classica Orientalia, Essays presented to Wiktor A. Daszewski on his $75^{\text {th }}$ Birthday, Polish Centre of Mediterranean Archaeology, Warsaw, 73-88.

J. Balty, "L'image de Méléagre et Atalante dans l'Antiquité tardive : la mosaïque de Sôran (Apamène)", D. Lauritzen - M. Tardieu (dir.), Le voyage des légendes, Hommages à Pierre Chuvin, Paris, 209-216.

J. Balty, "Rinceaux des mosaïques de Syrie et de Jordanie. Remarques sur le rinceau d'acanthe et sa signification", F. Baratte - V. Michel (eds.), Architecture et décor dans l'Orient chrétien (IV ${ }^{\mathrm{e}}-\mathrm{VIII}{ }^{\mathrm{e}}$ siècle). Actes de la Journée d'étude en hommage au Père Michele Piccirillo, Paris, 101-109.

J. Bardill, Brickstamps of Constantinople, Oxford.

J. Bardill, "Visualizing the Great Palace of the Byzantine Emperors at Constantinople. Archaeology, Text, and Topography”, F. A. Bauer (ed.), Visualisierungen von Herrschaft. Frühmittelelterliche Residenzen Gestalt und Zeremoniell. Internationales Kolloquium, Byzas 5, Istanbul, 5-45.

J. Bardill - J.W. Hayes, "Excavations beneath the peristyle mosaic in the great palace of the byzantine emperors: the pottery from site D, 1936", CArch 50, 27-40.

W. E. Betsch, The History, Production and Distribution of the Late Antique Capital in Constantinople, Philadelphia.

G. Brett, "The Mosaic of the Great Palace in Constantinople", JWCI V, 34-43.

G. Brett Gerard - W. J. Macaulay - R. B. K. Stevenson, The Great Palace of the Byzantine Emperors. Being a first Report on the Excavations carried out in Istanbul on Behalf of the Walker Trust (The University of St. Andrews) 1935-1938, Londres.

P. Brulé, "Promenade en pays pileux hellénique : de la physiologie à la physiognomonie", V. Dasen - J. Wilgaux (eds.), Langages et métaphores du corps dans le monde antique, Rennes, 133-151.

P. Brulé, Les sens du poil (grec), Paris. 
Castriota 1995

Chappuis Sandoz 2004

Cimok 2005

Coarelli - Sauron 1978

Dark 2007

Darmon 2005

Darmon 2008

Darmon 2011

Derwael in print

Duchesne-Guillemin 1975

Dunbabin 1999

Firatlı 1990

Forbes Irving 1990

Gawlikowski 2005

Gleason 1990

Gleason 1995

Golsenne 2012

Grabar 1963

Grabar 1966

Grabar 1979

Gros 2010

Guiglia Guidobaldi 2011

Guimier-Sorbets 2004

Gury 2014

Hachlili 2009

Hellenkemper-Salies 1987

Inglebert 2006

Isler-Kerenyi 2015
D. Castriota, The Ara Pacis Augustae and the Imagery of Abundance in Later Greek and Early Roman Imperial Art, Princeton.

L. Chappuis Sandoz, Terres d'abondance : paysages et images poétiques de la fertilité et du don dans la littérature latine, Bruxelles.

F. Cimok, Mosaics in İstanbul, İstanbul.

F. Coarelli-G. Sauron, "La tête Pentini. Contribution à l'approche méthodologique du néo-atticisme”, MEFRA 90, 705-726.

K. R. Dark, "Roman Architecture in The Great Palace of The Byzantine Emperors At Constantinople During The Sixth To Ninth Centuries", Byzantion 77, 87-105.

J.-P. Darmon, “Zôsimos de samosate, peintre-mosaïste actif à Zeugma autour de 200 ap. J.-C.”, Musiva et Sectilia I, 75-88.

J.-P. Darmon, "Phénoménologie de l'image divine dans la maison romaine : décor ou présence ? L'exemple de Dionysos", S. Estienne - D. Jaillard - N. Lubtchansky - C. Pouzadoux (eds.), Image et religion dans l'antiquité gréco-romaine, Collection du centre Jean Bérard, 28, Naples, 485-500.

J.-P. Darmon, “Merveilles de Zeugma (Turquie) ”, DossAParis 346, 38-45.

$\mathrm{S}$. Derwael, La tête végétalisée dans les décors romains. Origine d'un thème ornemental, $\mathrm{PhD}$ Thesis, Université de Liège - Sorbonne Université, Turnhout.

M. Duchesne-Guillemin, "Etude complémentaire de la « Mosaïque au Concert » de Hama et étude préliminaire d'une mosaïque inédite de Soueida", MemLinc XXX, 99-112.

K. Dunbabin, Mosaics of the Greek and Roman World, Cambridge.

N. Firatl1, La sculpture byzantine figurée au Musée archéologique d'Istanbul, Bibliothèque de l'Institut français d'Etudes anatoliennes d'Istanbul, XXX, Paris.

P. M. C. Forbes Irving, Metamorphosis in Greek Myths, Oxford.

M. Gawlikowski, “L'apothéose d'Odeinat sur une mosaïque récemment découverte à Palmyre”, CRAI 149-4, 1293-1304.

M. W. Gleason, “The Semiotics of Gender: Physiognomy and Self-Fashioning in the Second Century c.e.”, D. M. Halperin - J. J. Winkler - J. J. Zeitlin (eds.), Before Sexuality: The Construction of Erotic Experience in the Ancient Greek World, Princeton, 389-419.

M. W. Gleason, Making Men: Sophists and Self-Presentation in Ancient Rome, Princeton.

T. Golsenne, “L'ornement aujourd'hui”, Images Re-vues (online) 10, 2-28.

A. Grabar, Sculptures byzantines de Constantinople ( $\mathrm{IV}^{\mathrm{e}}-\mathrm{X}^{\mathrm{e}}$ siècle), Bibliothèque archéologique et historique de l'Institut français d'archéologie d'Istanbul, XVII, Paris.

A. Grabar, L'âge d'or de Justinien. De la mort de Théodose à l'Islam, Paris.

A. Grabar, Les voies de la création en iconographie chrétienne. Antiquité et Moyen Age, Paris.

P. Gros, “La notion d'ornamentum de Vitruve à Alberti”, Perspective (online) 1, 130-136.

A. Guiglia Guidobaldi, “The Marble Floor Decoration in Constantinople: Prolegomena to a Corpus”, M. Şahin (ed.), $11^{\text {th }}$ International Colloquium on Ancient Mosaics, Bursa, 413-436.

A.-M. Guimier-Sorbets, "Dionysos dans l'andrôn. L'iconographie des mosaïques de la maison grecque au IV et au III" siècle avant J.-C.”, MEFRA 116, 895-932.

F. Gury, "Les jardins romains étaient-ils bien entretenus ? Une esthétique du négligé ou l'expression d'une vitalité victorieuse ? Le dossier de la peinture romano-campanienne (30 avant-79 après J.-C.)”, E. Morvillez (dir.), Paradeisos genèse et métamorphose de la notion de paradis dans l'Antiquité, Actes du colloque international organisé par Eric Morvillez, Orient \& Méditerranée - archéologie, 15, Paris, 131-176.

R. Hachlili, Ancient Mosaic Pavements. Themes, Issues, and Trends. Selected Studies, Leiden-Boston.

G. Hellenkemper-Salies, "Die Datierung der Mosaiken im Großen Palast zu Kontantinopel”, BJ CLXXXVII, 273-308.

H. Inglebert, “Conclusions. Périodiser l'Antiquité tardive”, M. Ghilardi - C.J. Goddard - P. Porena (dir.), Les cités de l'Italie tardo-antique (IVe-VI ${ }^{\mathrm{e}}$ siècle), Institutions, économie, société, culture et religion, Colletion de l'Ecole française de Rome 369, Rome, 359-366.

C. Isler-Kerényi, Dionysos in classical Athens. An Understanding through Images, Religions in the 
Jobst 1987

Jobst 1995

Jobst 2005

Jobst 2006

Jobst - Vetters 1992

Jobst et al. 1997

Kellum 1994

King 2008

Lavagne 2000

Mazza 1982

Mendel 1914

Moreux 1970

Nordhagen 1963

Önal 2009

Onians 1951

Ovadiah 1984

Ovadiah 2001

Ovadiah - Ovadiah 1987

Ovadiah - Turnheim 1997

Parlasca 1983

Parrish 2005

Parrish 2006

Pensabene 2007

Piccirillo 1982

Piccirillo 1984a

Piccirillo 1984b

Piccirillo 1984c

Piccirillo 1986
Graeco-Roman World 181, Leiden-Boston.

W. Jobst, “Der Kaiserpalast von Konstantinopel und seine Mosaiken”, AW 18-3, 2-22.

W. Jobst, "Mosaikenforschung 1994. Bericht über die Arbeiten am Palastmosaik in Istanbul. Mozaik Araştırmaları 1994. İstanbul Saray Mozaiği Projesine İlişkin Rapor”, AnzWien 132, 29-49.

W. Jobst, "Das Palastmosaik von Konstantinopel. Chronologie und Ikonographie”, CMGR IX, 1083-1101.

W. Jobst, "Il mosaico del Palazzo imperiale di Costantinopoli. Restauro, iconografia, cronologia", Bizantinistica 8, 1-18.

W. Jobst - H. Vetters (eds.), Mosaikenforschung im Kaiserpalast von Konstantinopel Vorbericht über das Forschungs- und Restaurierungsprojekt am Palastmosaik in den Jahren 1983-1988, Österreichische Akademie der Wissenschaften, Philosophisch-Historische Klasse 228, Wien.

W. Jobst - B. Erdal - C. Gurtner, Istanbul, The Great Palace Mosaic. The Story of its Exploration, Preservation and Exhibition 1983-1997, İstanbul-Wien.

B. A. Kellum, "What we see and what we dont' see. Narrative structure of the Ara Pacis Augustae", Art History 17-1, 26-45.

H. King, "Barbes, sang et genre : afficher la différence dans le monde antique”, V. Dasen - J. Wilgaux (dir.), Langages et métaphores du corps dans le monde antique, Rennes, 153-168.

H. Lavagne, "La mosaïque chrétienne, prolongement de l'art antique ou langage nouveau ?", H. Lavagne - E. de Balanda - A. Uribe Echeverria (dir.), Mosaïque. Trésor de la latinité des origines à nos jours, Quetigny, 221225.

A. Mazza, "La maschera fogliata : una figura dei repertori ellenistico-orientali riproposta in ambito-bizantino", JbÖByz XXXII, 5, 23-32.

G. Mendel, Musées impériaux ottomans. Catalogue des sculptures grecques, romaines et byzantines II, İstanbul.

B. Moreux, "Dèmèter et Dionysos dans la septième Isthmique de Pindare”, REG 83, 1-14.

P. J. Nordhagen, "The Mosaics of the Great Palace of the Byzantine Emperors", ByzZ LVI, 53-68.

M. Önal, A corpus. Zeugma Mosaics, İstanbul.

R. B. Onians, Origins of European Thought: About the Body, the Mind, the Soul, the World, Time, and Fate, Cambridge.

A. Ovadiah, "Mosaic Pavements Discovered in the Last Decade in Israel (1970-1980)", R. Farioli (ed.), III colloquio internazionale sul mosaico antico II, Ravenna, 309-320.

A. Ovadiah, "The « Peopled» Scroll Motif in the Land of Israel in Late Antiquity", N. Kenaan-Kedar - A. Ovadiah (eds.), The Metamorphosis of Marginal Images: From Antiquity to Present Time, Tel Aviv, 1-10.

A. Ovadiah - R. Ovadiah, Hellenistic, Roman and Early Byzantine Mosaic Pavements in Israël, Rome.

A. Ovadiah - Y. Turnheim, "The Female Figure in the Dionysiac Mosaic at Sepphoris”, RdA XXI, 107-116.

K. Parlasca, "Zum Provinzenmosaik von Belkis-Seleukeia am Euphrat”, Mosaïque : recueil d'hommages à Henri Stern, Paris, 287-295.

D. Parrish, "The art-historical context of the Great Palace mosaic at Constantinople", CMGR IX, 1103-1117.

D. Parrish, "The Great Palace Mosaic in Constantinople: its Varied Sources and its Sociological Context", C.C. Mattusch - A.A. Donohue - A. Brauer (eds.), Common Ground: Archaeology, Art, Science, and Humanities. Proceedings of the XVI ${ }^{\text {th }}$ International Congress of Classical Archaeology, Boston, Oxford, 593-596.

P. Pensabene, "Gli elementi marmorei della scena: classificazione tipologica e inquadramento nella storia degli studi della decorazione architettonica in Asia Minore”, D. De Bernardi Ferrero - G. Ciotta - P. Pensabene (dir.), Il teatro di Hierapolis di Frigia, Restauro, architettura ed epigrafia, Genova, 229-388.

M. Piccirillo, "Il complesso monastico di Zay el-Gharbi e la diocesi di Gadara della Perea", G. C. Bottini (dir.), Studia Hierosolymitana. Volume III, Nell’Ottavo Centenario Francescano (1182-1982), StBiFranc 30, Jerusalem, 359-378.

M. Piccirillo, “The Umayyad Churches of Jordan”, AAJ 28, 333-341.

M. Piccirillo, "Eglises locales des provinces Palestrina Prima et Secunda", Le monde de la Bible 35, 8-12.

M. Piccirillo, "Gerasa”, Le monde de la Bible 35, 17-21.

M. Piccirillo, “Catalogo”, M. Piccirillo (dir.), I mosaici di Giordania, Rome, 219-233. 
Piccirillo 1989a

Piccirillo 1989b

Piccirillo 1989c

Piccirillo 1995

Piccirillo 2002

Piccirillo 2003

Raeck 1992

Raeck 1997

Roe 1995

Sauron 1978

Soler 2019

Swift 2009

Talbot Rice 1958

Talgam - Weiss 2004

Toynbee - Ward-Perkins 1950 J. M. C. Toynbee - J. B. Ward Perkins, "Peopled scrolls : a hellenistic Motif in Imperial Art", BSR XVIII, 1-43. Trilling 1989

Turcan 1958

Turcan 2007

Turnovsky 1992

Turnovsky 1999

Vadé 1977

Van Elderen 1970

Versnel 1990

Westbrook 2019

M. Piccirillo, "Les mosaïques de Justinien à Yazid II”, M. Piccirillo (ed.), Mosaïques byzantines de Jordanie. Catalogue de l'exposition du Musée de la civilisation gallo-romaine de Lyon, Lyon, 27-140.

M. Piccirillo, "L'école de mosaïques de Madaba”, M. Piccirillo (ed.), Mosaïques byzantines de Jordanie. Catalogue de l'exposition du Musée de la civilisation gallo-romaine de Lyon, Lyon, 141-148.

M. Piccirillo, Madaba. Le Chiese e i Mosaici, Milano.

M. Piccirillo, "Il mosaico pavimentale di Giordania come fonte storica di un'epoca : III (1985-87)", L. Roger (ed.), Fifth international colloquium on ancient mosaics held at Bath, England, JRA supplementary 9, 65-87.

M. Piccirillo, L'Arabie chrétienne, Paris.

M. Piccirillo, "Evolution de l'architecture chrétienne en Jordanie d'après les monuments de la région de Madaba", N. Duval (ed.), Les églises de Jordanie et leurs mosaïques. Actes de la journée d'études organisée à l'occasion de l'inauguration de l'exposition « Mosaïques byzantines de Jordanie » au Musée de la Civilisation gallo-romaine de Lyon en avril 1989, Beyrouth, 3-15.

W. Raeck, Modernisierte Mythen. Zum Umgang der Spätantike mit klassischen Bildthemen, Stuttgart.

W. Raeck, "Mythos und Selbstdarstellung in der spätantiken Kunst. Das Beispiel der Meleagersage", S. Isager - B. Poulsen (eds.), Patron and Pavements in Late Antiquity, Odense, 30-37.

P. G. Roe, "Style, society, myth, and structure", C. Carr - J. Neitzel (eds.), Style, Society, and Person: Archaeological and Ethnological Perspectives, NY, 27-76.

G. Sauron, "Corollaire : Notes sur la diffusion de frises de mosaïques hellénistiques à décor de rinceaux", MEFRA 90, 727-751.

J. Soler, "Virgile, prophète du monothéisme dans l'Antiquité tardive ?", RHistRel 4, 703-730.

E. Swift, Style and Function in Roman Decoration. Living with Objects and Interiors, Farnham-Burlington.

D. Talbot Rice, The Great Palace of the Byzantine Emperors. Second Report, Edinburgh.

R. Talgam - Z. Weiss, The Mosaics of the House of Dionysos at Sepphoris, Qedem 44, Jerusalem.

J. Trilling, "The Soul of the Empire: Style and Meaning in the Mosaic Pavement of the Byzantine Imperial Palace in Constantinople", DOP 43, 27-72.

R. Turcan, "Dionysos Dimorphos : une illustration de la théologie de Bacchus dans l'art funéraire”, Mélanges d'archéologie et d'histoire 70, 243-294.

R. Turcan, "Dieux barbus du cycle bachique”, JSav, 1, 87-112.

P. Turnovsky, "Fundbericht", W. Jobst, - H. Vetters (dir.), Mosaikenforschung im Kaiserpalast von Konstantinopel. Vorbericht über das Forschungs- und Restauratierungsprojekt am Palastmosaik in den Jahren 1983-1988, Österreichische Akademie der Wissenschaften, Phil.-hist. Klasse, Denkschriften 228, Wien, 43-62.

P. Turnovsky, “Typologie und Chronologie des Fundstoffes unter dem Palastmosaik”, W. Jobst - R. Kaster - V. Scheibelreiter (dir.), Neue Forschungen und Restauratierungen im byzantinischen Kaiserpalast von Istanbul. Akten der Internationalen Fachtagung vom 6.-8. November 1991 in Istanbul, Wien, 55-62.

Y. Vadé, "Sur la maternité du chêne et de la pierre", RHistRel 191, 3-41.

B. Van Elderen, "The Byzantine Church at Swafieh", AAJ XV, 25-27.

H. S. Versnel, Inconsistencies in Greek and Roman Religion. 1. Ter unus : Isis, Dionysos, Hermes. Three Studies in Henotheism, Studies in Greek and Roman Religion 6, Leiden.

N. Westbrook, The Great Palace in Constantinople: An Architectural Interpretation, Turnhout. 